Article

\title{
Size- and Surface-Dependent Solubility of Cadmium Telluride in Aqueous Solutions
}

\author{
Renate Zapf-Gottwick ${ }^{1, *}$, Matthias Zorn ${ }^{1}$, Jessica Nover ${ }^{1}$, Michael Koch ${ }^{2}$, Carolin Feifel ${ }^{2}$ and Jürgen H. Werner ${ }^{1}$ \\ 1 Institute for Photovoltaics and Research Center SCoPE, University of Stuttgart, 70569 Stuttgart, Germany; \\ zorn_matthias@yahoo.de (M.Z.); jessica.nover@ipv.uni-stuttgart.de (J.N.); \\ juergen.werner@ipv.uni-stuttgart.de (J.H.W.) \\ 2 Institute for Sanitary Engineering, Water Quality, and Solid Waste Management, University of Stuttgart, \\ 70569 Stuttgart, Germany; michael.koch@iswa.uni-stuttgart.de (M.K.); \\ carolin.feifel@iswa.uni-stuttgart.de (C.F.) \\ * Correspondence: renate.zapf-gottwick@ipv.uni-stuttgart.de; Tel.: +49-711-685-69225
}

Citation: Zapf-Gottwick, R.; Zorn, M.; Nover, J.; Koch, M.; Feifel, C.; Werner, J.H. Size- and Surface-Dependent Solubility of Cadmium Telluride in Aqueous Solutions. Energies 2021, 14, 398. https://doi.org/10.3390/en14020398

Received: 20 November 2020 Accepted: 23 December 2020 Published: 12 January 2021

Publisher's Note: MDPI stays neutral with regard to jurisdictional clai$\mathrm{ms}$ in published maps and institutional affiliations.

Copyright: (C) 2021 by the authors. Licensee MDPI, Basel, Switzerland. This article is an open access article distributed under the terms and conditions of the Creative Commons Attribution (CC BY) license (https:// creativecommons.org/licenses/by/ $4.0 /)$.

\begin{abstract}
Due to the toxicity of cadmium (Cd) and the scarcity of telluride (Te), CdTe-based photovoltaic modules have been under discussion during the last few years. In particular, the stability of CdTe in aqueous solutions is under debate. Here we show that the stability of CdTe depends not only on the $\mathrm{pH}$ of water-based solutions but also on size and surface treatment of CdTe particles. We compare milled module pieces with CdTe powders of different particle size. The leaching of CdTe is conditioned by the outdiffusion of $\mathrm{Cd}$ and $\mathrm{Te}$ at the interface between CdTe particles and the aqueous solution. The smaller the particle size, the faster the leaching. Therefore, milled module pieces decompose faster than CdTe powders with relatively large grains. We observe a dependence on time $t$ according to $t^{0.43}$. The room temperature diffusion coefficients are calculated as $D_{C d} \approx 3 \times 10^{-17} \mathrm{~cm}^{2} / \mathrm{s}$ for $\mathrm{Cd}$, and $D_{\mathrm{Te}} \approx 1.5 \times 10^{-17} \mathrm{~cm}^{2} / \mathrm{s}$ for Te in pH4. The chemical instability in aqueous solutions follows thermodynamic considerations. The solution behavior of $\mathrm{Cd}$ and Te depends on the $\mathrm{pH}$ value and the redox potential of the aqueous solutions. Chemical treatments such as those used in solar cell production modify the surface of the CdTe particles and their leaching behavior.
\end{abstract}

Keywords: cadmium telluride; toxicity; solar cells; solubility elution; $\mathrm{pH}$ dependence

\section{Introduction}

At present, every year, small- and large-area photovoltaic systems are installed on the basis of cadmium telluride ( $\mathrm{CdTe}$ )-containing modules with a power around $3 \mathrm{GW}_{\mathrm{p}}$, which corresponds to an annual area of $20 \mathrm{~km}^{2}$ and an annual distribution of about 230 tons of Cd. (A typical CdTe module of $16 \%$ efficiency $\left(160 \mathrm{~W} / \mathrm{m}^{2}\right.$ ) with a CdTe thickness of around $4 \mu \mathrm{m}$ contains about $78 \mathrm{mg} \mathrm{Cd}$ per W. At present (2020) about $3 \mathrm{GWp}$ of CdTe modules are produced worldwide per year.) At the end of 2019, about $600 \mathrm{GW}_{\mathrm{p}}$ module power were installed worldwide. From these, between 25 and $30 \mathrm{GW}_{\mathrm{p}}$, i.e., between $4 \%$ and $5 \%$ are modules on the basis of CdTe. This number corresponds to an area of 170 to $200 \mathrm{~km}^{2}$ for the CdTe modules containing a total mass of about $2000 \mathrm{t}$ of $\mathrm{Cd}$. This enormous distribution of CdTe on large areas clearly raises the question of the environmental effects of the toxic element $\mathrm{Cd}$ as well as of the compound CdTe.

Despite the toxicity and the cancerogenic action of the element $\mathrm{Cd}$, its use in $\mathrm{CdTe}$ modules still is not yet legally restricted within the European Union. The lack of legal sanctions against CdTe modules usually is justified by arguing that cadmium telluride is "chemically stable", in particular in aqueous solutions, for example, in rainwater. Indeed, when compared to the elements $\mathrm{Cd}$ and $\mathrm{Te}$, as well as to other $\mathrm{Cd}$ compounds, the crystalline compound cadmium telluride (CdTe) has a higher stability [1]. Therefore, intact CdTe photovoltaic modules seem to impose no risks for environment and health [2]: In 
unbroken modules, the CdTe layers are protected by two glass plates and the edge sealing of the module. However, at the end of use of intact photovoltaic modules questions remain concerning the decommissioning and recycling of CdTe [3]. Possible ways of recycling of the CdTe-modules are crushing and leaching in acids like sulfuric acid with low $\mathrm{pH}$ $(\mathrm{pH}<1)[4,5]$.

For a long time it has been stated that even unprotected CdTe layers would only decompose in strong acids. Neutral water and rainwater were stated to not decompose CdTe [1]. These statements were based on experiments that were carried out over $24 \mathrm{~h}$ only. Recently, however, we gave direct experimental proof that CdTe layers in photovoltaic module pieces do not only decompose in strong acids, but (if waited long enough) even in neutral water $[6,7]$.

During the course of our studies [6,7] we speculated if the thickness and/or the grain size of the CdTe layers might have an influence on the stability and solubility of CdTe in aqueous solutions. In the case of our commercially obtained CdTe solar modules, we measured a thickness $d_{\mathrm{CdTe}} \approx 3 \mu \mathrm{m}$ for the CdTe layer. This thickness is large enough to absorb about $90 \%$ of the sun's light with photon energies $h v \geq E_{g}$ with the value $E_{g}=1.45 \mathrm{eV}$ for the band gap of CdTe [8-10]. The size of CdTe particles and/or illumination may also play a role in the decomposition in aqueous solutions: illuminated CdTe particles of nm size show a higher mobilization of $\mathrm{Cd}$ due to a photochemical reaction [11]. The grain size of the crystals in the CdTe module pieces is in the $\mu$ m-range [12], which we confirmed by own measurements.

Apart from thickness and/or grain size, the stability of the compound CdTe might also be influenced by the surface structure of the CdTe layers. During the production process of the solar module, the surface of the CdTe is modified by several steps [13-15], which alter the surface of the CdTe layers for solar modules. These steps may also change the solubility of CdTe layers either by protecting them or even by making them "weaker" against the attack of aqueous solution.

The present study reports on the influence of the grain size, and the surface properties of CdTe on its chemical stability. To cover a wide range of parameters, for most of our experiments, we do not only use CdTe-layers from solar modules. Instead, we also process CdTe powders of different grain sizes, and we emulate the influence of solar cell processes on these CdTe powders. Then, the differently prepared samples undergo stability experiments in aqueous solutions with $\mathrm{pH}$-values of $\mathrm{pH}=4,7$, and 10 . Finally, we are able to explain the dissolution behavior of the CdTe layers not only qualitatively, but also quantitatively: (i) The dissolution of the CdTe-particles is a consequence of the diffusion of the $\mathrm{Cd}$ and Te towards the interface between the CdTe particles and the solution. (ii) The higher surface to volume ratio of small particles is responsible for their faster dissolution. (iii) The dissolution follows a dependence on time $t$ according to $t^{0.43}$. This experimentally observed power law is in line with a pharmaceutical model for spherical particles.

\section{Experimental}

\subsection{Cadmium Telluride (CdTe) Sources}

Our leaching experiments are carried out on three different CdTe-powders, commercially available from company Sigma Aldrich [16]. The powders have a purity between 99.99\% and 99.9999\%. In addition, we compare the results to those obtained from milled module pieces out of the experiments from reference [6]. In total, we perform five different kinds of leaching experiment, using four different sources for the samples:

1. Three sieved CdTe-powders with different maximal grain diameter $d$ :

(i) $\mathrm{CdTe}_{250}$ with $d_{250} \leq 250 \mu \mathrm{m}, d_{\text {mean, } 250} \approx 4$ to $5 \mu \mathrm{m}$ (see below)

(ii) $\quad \mathrm{CdTe}_{840}$ with $d_{840} \leq 840 \mu \mathrm{m}, d_{\text {mean }, 840} \approx 9 \mu \mathrm{m}$

(iii) $\quad \mathrm{CdTe}_{3000}$ with $d_{3000} \leq 3000 \mu \mathrm{m}$.

2. $\mathrm{CdTe}_{3, \mathrm{~m}}$ pieces from milled modules: 
The milled module particles from our reference [6] have a diameter around $200 \mu \mathrm{m}$ and contain a CdTe layer of $3 \mu \mathrm{m}$ thickness surrounded by the contacting metals and the glass layers from the front and back glass of the laminated module. After milling, the particles have a mean size $d_{\text {mean }, 3, \mathrm{~m}} \approx 1.2 \mu \mathrm{m}$ (shown below).

The production of the powder involves a subsequent sieving by the manufacturer, therefore only a small amount of particles shows the given maximum sizes $d_{250 \text {,max }}$, $d_{840, \max }, d_{3000, \max }$. Determination of the powders' surface by nitrogen adsorption with the Brunauer-Emett-Teller (BET)-method yields the surface area $A$. For $\mathrm{CdTe}_{250}$, we obtain $A_{250} \approx 0.22 \mathrm{~m}^{2} / \mathrm{g}$. From this value and assuming a spherical shape, we derive the above given mean particle diameter $d_{\text {mean,250 }} \approx 4.6 \mu \mathrm{m}$ compared to $d_{250, \max } \approx 250 \mu \mathrm{m}$. In contrast, for $\mathrm{CdTe}_{840}$ we obtain $A_{840} \approx 0.11 \mathrm{~m}^{2} / \mathrm{g}$ with a mean particle diameter $d_{\text {mean, } 840} \approx 9 \mu \mathrm{m}$ compared to $d_{840, \max } \approx 840 \mu \mathrm{m}$. Thus, for the same mass of CdTe, the relative diameter $r_{\text {diameter }}=9 \mu \mathrm{m} / 4.6 \mu \mathrm{m}$ of the directly measured (with BET) surface areas amounts to about $\mathrm{r}_{\text {diameter }} \approx 2$. If we calculate the diameter ratio only from the largest grains ( $\left.840 \mathrm{vs} .250 \mu \mathrm{m}\right)$, the relative ratio $r_{\text {grain }}$ is $r_{\text {grain }}=840 \mu \mathrm{m} / 250 \mu \mathrm{m}=3.4$.
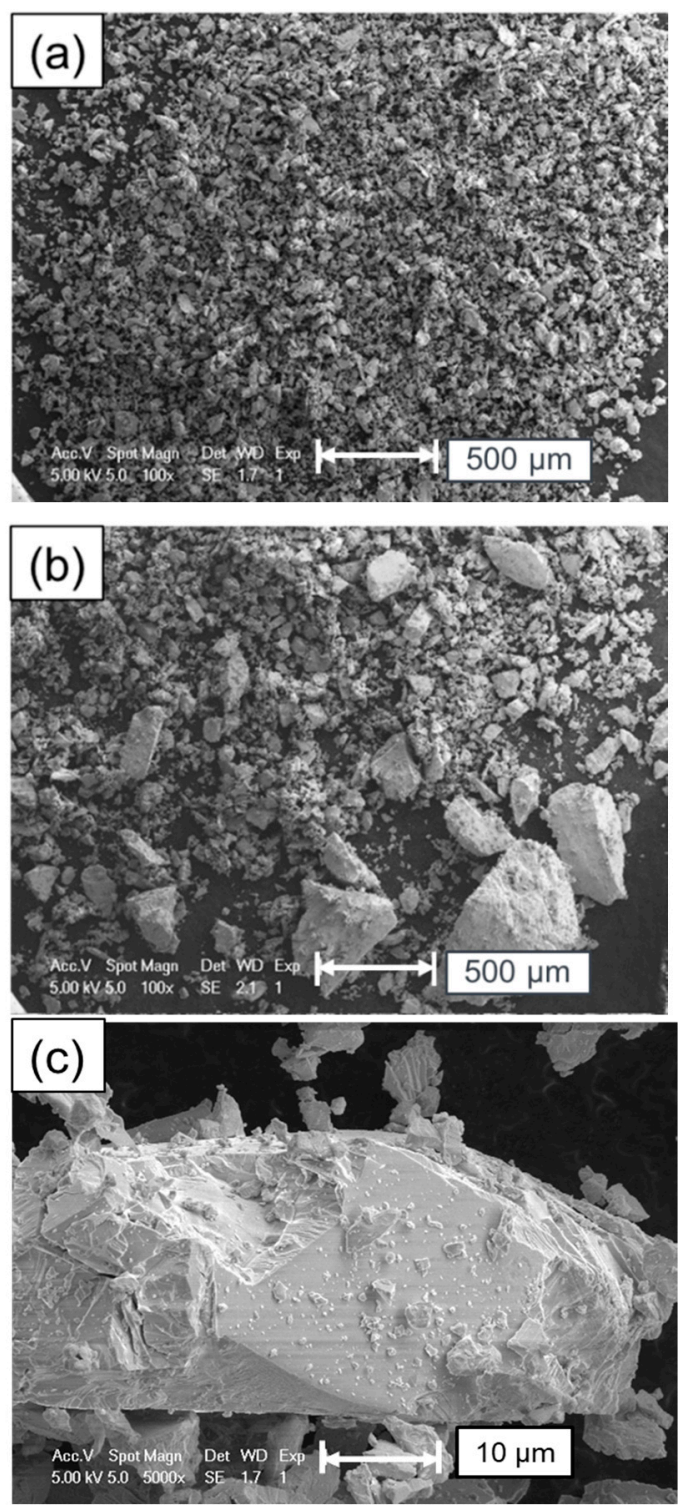

Figure 1. Cont. 


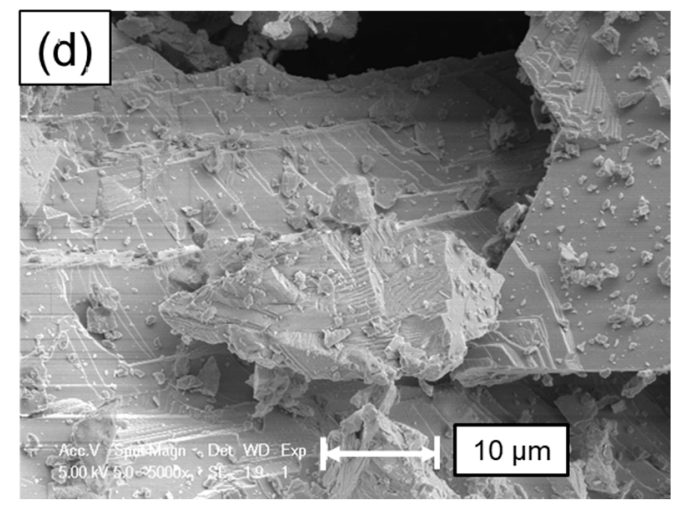

Figure 1. Secondary electron images taken by scanning electron microscope (SEM) of cadmium telluride CdTe powders: (a) CdTe 250 with grain sizes $d_{250}<250 \mu \mathrm{m}$ and (b) $\mathrm{CdTe}_{840}$ with grain sizes $d_{840}<840 \mu \mathrm{m}$. Due to sieving, the powder contains also smaller sized grains: (c) $\mathrm{CdTe}_{250}$ with grain sizes $d_{250}<250 \mu \mathrm{m}$ and (d) $\mathrm{CdTe}_{840}$ with grain sizes $d_{840}<840 \mu \mathrm{m}$ with higher resolution.

Figure 1a,b show micrographs taken with a Philips XL30 SFEG scanning electron microscope (SEM) from the as received CdTe powders. Figure 1a shows $\mathrm{CdTe}_{250}$ with the maximum particle size $d_{250 \text {,max }} \approx 250 \mu \mathrm{m}$, whereas Figure $1 \mathrm{~b}$ exhibits maximal sizes $d_{840, \max } \approx 840 \mu \mathrm{m}$ for the $\mathrm{CdTe}_{840}$ powder. Higher-resolution measurements with the SEM in Figure 1c for $\mathrm{CdTe}_{250}$ and in Figure $1 \mathrm{~d}$ for $\mathrm{CdTe}_{840}$ indicate even smaller grain sizes than $1 \mu \mathrm{m}$ for the sieved powder. The mean sizes $d_{\text {mean,250 }} \approx 4.6 \mu \mathrm{m}$ and $d_{\text {mean,840 }} \approx 9 \mu \mathrm{m}$ from the BET measurements roughly correspond with the SEM data for these powders.

Figure $2 \mathrm{a}, \mathrm{b}$ show micrographs of module pieces which were milled according to the recipes of reference [6]. If one compares Figure 2a with Figure 1a,b it seems that the milled module pieces have approximately the same particle size as the CdTe powders. However, measurements on a higher resolution scale indicate a much smaller particle size for the milled module pieces: From Figure $2 \mathrm{~b}$ we derive a mean particle size $d_{\text {mean,3,m }} \approx 1 \mu \mathrm{m}$ compared to the much larger particle diameter of the $\mathrm{CdTe}_{250}$ powder from Figure 2c. For the $\mathrm{CdTe}_{3000}$ powder, from microscope pictures, we estimate a mean particle size around $d_{\text {mean,3000 }} \approx 200 \mu \mathrm{m}$. For further consideration of a size dependent elution we take the mean particle sizes into account.

Therefore, if we take the mean particle sizes of the $\mathrm{CdTe}_{250}$ powder as a reference (we have most leaching data for those films), the ratio of the mean particle size behaves as:

$d_{\text {mean,3,m }}: d_{\text {mean,250 }}: d_{\text {mean,840 }}: d_{\text {mean }, 3000} \approx 1 \mu \mathrm{m}: 4.5 \mu \mathrm{m}: 9 \mu \mathrm{m}: 200 \mu \mathrm{m}=0.2: 1: 2: 50$

Thus, if we take the $\mathrm{CdTe}_{250}$ powder as a reference, and assume that the etched mass $C$ of CdTe in the solution is proportional to the relative ratio of the particles' surface/volume ratio, i.e., to what we expect to be the concentrations $C \propto 1 / d_{\text {mean }}$, it roughly holds that:

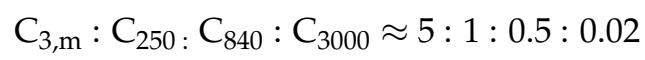

for the eluted mass $C_{3, m}$ from the milled module pieces, $C_{250}$ from the $\mathrm{CdTe}_{250}$ powder, $C_{840}$ from the $\mathrm{CdTe}_{840}$ powder, and $C_{3000}$ from the $\mathrm{CdTe}_{3000}$ powder. Here, for example, the $C_{3, \mathrm{~m}}$ is an abbreviation, standing for $C_{3, \mathrm{~m}, \mathrm{Cd}}$ (the relative eluted mass of $\mathrm{Cd}$ ) as well as for $C_{3, \mathrm{~m}, \mathrm{Te}}$ (the concentration of $\mathrm{Te}$ ) in the eluting liquid.

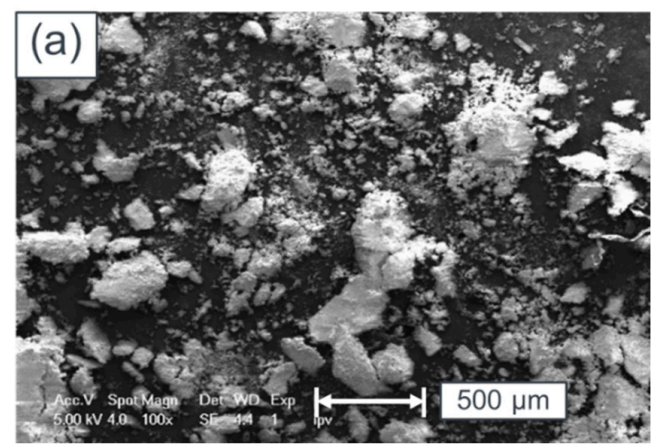

Figure 2. Cont. 

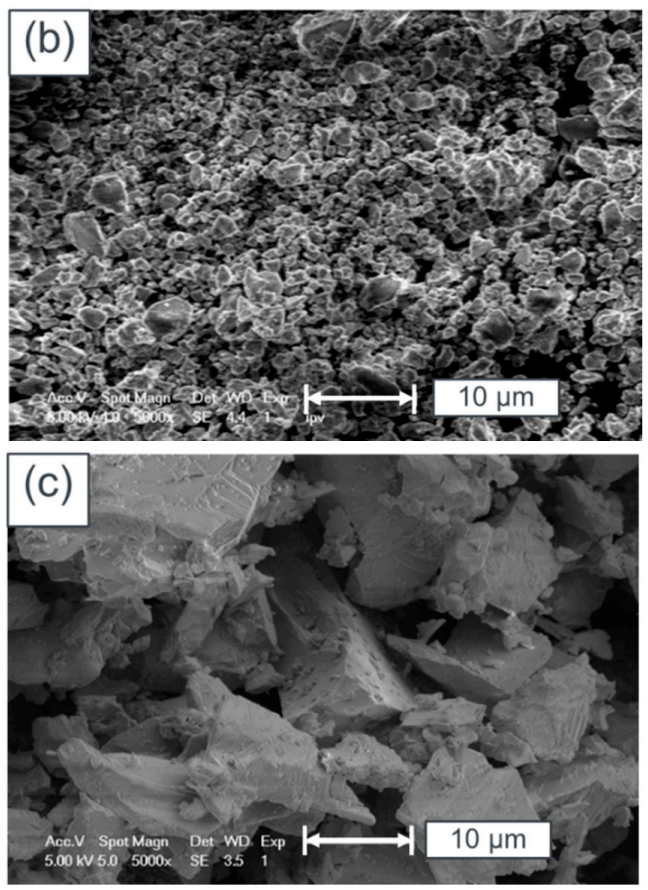

Figure 2. Secondary electron images from milled, unleached CdTe module pieces (a) same resolution as in Figure 1. (b) higher resolution. (c) Higher resolution micrograph from unleached $\mathrm{CdTe}_{250}$ powder for comparison. Compared to the sieved CdTe powders, the milled module pieces have a much smaller mean particle size.

\subsection{Samples for Leaching Experiments}

We use five different kinds of sample for the leaching experiments:

- $\quad$ The untreated CdTe-powders from Sigma Aldrich as described in Section 2.1.

- $\quad$ Solar-cell-like activated CdTe-powder CdTe $\mathrm{act}_{\text {act }}$ as described in Section 2.3.

- $\quad$ Solar-cell-like etched CdTe-powder CdTe etch as described in Section 2.3.

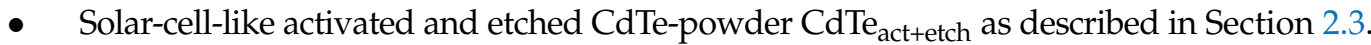

- $\quad$ The milled module pieces $\mathrm{CdTe}_{3, \mathrm{~m}}$ as described in Section 2.1.

The activated and/or etched CdTe powders undergo "solar-cell-like" processes that are similar to those used in the production of CdTe solar modules, as described below.

\subsection{Solar-Cell-Like Processing}

During the production process of the solar module, the surface of the CdTe powder is modified by two steps, which improve the cells' efficiency $[10,13]$ :

- "Activation" $[10,13,14]$; and

- "Etching" [15].

Activation: The fabrication of the cells (in a superstrate configuration) starts with the deposition of a transparent conductive oxide (TCO) on a glass substrate, followed by depositing an n-type cadmium sulfide (CdS) layer. Then the activation occurs in the cell processes: after deposition of p-type $\mathrm{CdTe}$ on the $\mathrm{CdS}$, an activation with cadmium chloride $\left(\mathrm{CdCl}_{2}\right)$ via an annealing step increases the grain size of the CdTe and $\mathrm{CdS}$ and, therefore, the efficiency. [12] Interdiffusion of Te and S at the CdTe/CdS interface could also be found [14].

Etching: Then, before the deposition of molybdenum for the ohmic back contact, the surface of the low doped p-type CdTe, undergoes etching by a nitric-phosphoric acid mixture (N-P etch). This etching process creates a phosphorus rich and a Te enriched layer [15]. Soluble Cd compounds are removed leaving insoluble Te compounds on the surface. Moreover, a Te cap on the individual grains due to etching enlarges the contact area and thus lowers the contact resistance between the Mo metal and the CdTe layer [10]. 
The N-P etch etches primarily at grain boundaries. This effect leads to an elemental layer of Te with a thickness of $8 \mathrm{~nm}$ leaving Cd on top with a concentration of $10 \%[12,17]$.

\subsubsection{Activated CdTe Powder CdTe ${ }_{\text {act }}$}

Our experiments on the small sized CdTe-powder with $d_{250} \leq 250 \mu \mathrm{m}$ simulate the "activation step" in the preparation of CdTe layers for solar modules. Following the processes of references [18-20] we use a chloride treatment and subsequent annealing: The $\mathrm{CdCl}_{2}$ treatment is done in methanol which contains dissolved $\mathrm{CdCl}_{2}$-powder. The activation of CdTe depends on the ratio of $\mathrm{CdTe}$ to $\mathrm{CdCl}_{2}$ : with a given CdTe thickness $d_{\mathrm{CdTe}}=4 \mu \mathrm{m}$ the optimal thickness of the $\mathrm{CdCl}_{2}$-layer should be $d_{\mathrm{CdCl}}=0.35 \mu \mathrm{m}[18,19]$. For activation of the powder we use the ratio of thicknesses as a ratio for the mass ratio CdTe: $\mathrm{CdCl}_{2}=1: 0.057$ with a mass density of $6.20 \mathrm{~g} / \mathrm{cm}^{3}$ for CdTe and $4.047 \mathrm{~g} / \mathrm{cm}^{3}$ for $\mathrm{CdCl}_{2}$. The $\mathrm{CdCl}_{2}$-powder dissolves in methanol with a maximum solubility of $1.5 \mathrm{~g} \mathrm{CdCl}_{2}$ in $100 \mathrm{~mL}$ methanol [20]. We stay below this value and dissolve the mass $m_{C d C l 2}=0.286 \mathrm{~g}$ of $\mathrm{CdCl}_{2}$ in the mass $m_{\text {Meth }}=28.6 \mathrm{~g}$ of methanol within a time $t_{u \mathrm{sb}}=45 \mathrm{~min}$ by using an ultrasonic bath. Then, CdTe of mass $m_{C d T e}=5 \mathrm{~g}$ is suspended in the $\mathrm{CdCl}_{2} /$ methanol mixture in the mass ratio CdTe: $\mathrm{CdCl}_{2}=1: 0.057$. Thereafter, in order to prepare the powder for the activation step, a rotary evaporator evaporates the methanol at a temperature $T_{\text {rot }}$ $=40^{\circ} \mathrm{C}$ and a pressure $p_{\text {rot }}=200$ mbar. Afterwards, freeze drying removes the possible remaining methanol. Finally, we perform the annealing in order to support grain growth by the activation. We anneal the $\mathrm{CdTe} / \mathrm{CdCl}_{2}$-powder for a time $t_{\mathrm{sb}}=30 \mathrm{~min}$ in a sand bath with a sand temperature $T_{\text {sand }}=360{ }^{\circ} \mathrm{C}$. These parameters also follow the processes described in references $[18,20]$. The excess $\mathrm{CdCl}_{2}$ which might deposit on the surface of the CdTe powder is not rinsed after heat treatment to see the effect of change in the surface of CdTe.

\subsubsection{Etched CdTe Powder $\mathrm{CdTe}_{\text {etch }}$}

We also simulate the wet chemical etching for oxide removal and formation of a Te-rich surface as done on CdTe in solar cell fabrication. For that purpose, following reference [10], we use a mixture of $65 \%$ nitric acid $\left(\mathrm{HNO}_{3}\right)$ and $85 \%$ phosphoric acid $\left(\mathrm{H}_{3} \mathrm{PO}_{4}\right)$ (NP-etch) in the volume ratios $\mathrm{HNO}_{3}: \mathrm{H}_{3} \mathrm{PO}_{4}: \mathrm{DI}$-water $=1: 70: 29$ for a time $t_{\text {etch }}=60 \mathrm{~s}$. Then, a paper filter separates the etched $\mathrm{CdTe}_{\text {etch }}$ from the acid, followed by rinsing with water for a time $t_{\text {rinse }}=10 \mathrm{~min}$ in order to remove remaining acid. Freeze-drying instead of annealing makes sure that the etched CdTe powder does not oxidize [21].

\subsubsection{Activated and Etched CdTe Powder CdTe act+etch}

This preparation uses first step A, then step B.

\subsection{Leaching Solutions and Sampling}

The leaching experiments are carried out at room temperature. To test the chemical stability of the differently prepared CdTe powders, we use the following three buffered aqueous solutions:

(a) pH4: $3.9 \mathrm{~g}$ citric acid with $4.5 \mathrm{~g}$ disodium hydrogen phosphate in $1000 \mathrm{~mL}$ deionized water.

(b) pH7: $1.2 \mathrm{~g}$ citric acid with $9.6 \mathrm{~g}$ disodium hydrogen phosphate in $1000 \mathrm{~mL}$ deionized water.

(c) pH10: $2.0 \mathrm{~g}$ sodium hydroxide in $1000 \mathrm{~mL}$ deionized water.

For the leaching experiments, $100 \mathrm{mg}$ CdTe-powder (either in the unprocessed or in the solar-cell-like processed state) is put in bottles with $100 \mathrm{~mL}$ of aqueous solution, which corresponds to a concentration of $1 \mathrm{~g} / \mathrm{L}$. Bottles are made out of low-density polyethylene (LDPE) to ensure that there is no reaction of the solutions with the material, especially in acidic solutions. To make sure that the $\mathrm{pH}$ value remains constant, we use buffered solutions. The buffered solutions stabilize the $\mathrm{pH}$ values during the experiments, while the $\mathrm{pH}$ value is monitored on a regular basis.

The bottles with the aqueous solutions and the different CdTe powders are shaken overhead for several weeks at room temperature. To exclude a photochemical reaction 
during the experiments, the bottles are packed in cartons, which are impervious to light. For the analysis of leached elements, we periodically take samples from the solutions. The volume and composition of the leaching solution is corrected by the amount of solution and leached elements, which are removed during sampling. Inductively coupled plasma mass spectroscopy (ICP-MS) analyzes the amount of leached substances. The measurement uncertainty is around $\pm 10 \%$. All leaching experiments are carried out in triplicate, thus each one of our data points represents the mean value of three experiments.

Our $\mathrm{pH}$ values are representative for $\mathrm{pHs}$ that could occur in the environment whether in rain, ground water or within waste disposal sites-from the acidic $\mathrm{pH} 4$ to the alkaline $\mathrm{pH} 10$. In comparison, the $\mathrm{pH}$ values of rainwater and landfills differ with location and conditions: In Brazil, the $\mathrm{pH}$ of rain water ranges within $4.2<\mathrm{pH}<6.1$ [22], whereas in Germany it ranges within $4.1<\mathrm{pH}<5.3$ [23]. Depending on the classification of waste, landfills in Germany range within $3.4<\mathrm{pH}<11.9$ [24], i.e., from strongly acidic to strongly alkaline. In contrast, seawater with $7.5<\mathrm{pH}<8.5$ [25], covers a relatively narrow $\mathrm{pH}$ range, more in the range of neutral water with $\mathrm{pH}$. Mineralized water also, depending on its origin, varies in the range $4.9<\mathrm{pH}<8.4$ [26]. The solubility of almost all elements in aqueous solutions strongly depends on the $\mathrm{pH}$ of the solution. Our experiments aim at the quantification of this $\mathrm{pH}$ dependency. Thus, e.g., the experiments at $\mathrm{pH} 4$ and $\mathrm{pH}$, allow us to conclude about the behavior at $\mathrm{pH}$ values in between.

\section{Leaching Results}

Here, we show the results of the leaching of CdTe powder as well as of the milled module pieces in aqueous solutions with the three different $\mathrm{pH}$. The $\mathrm{pH}$ value of the eluted milled module pieces (but not for the powders) varied because of non-buffered solutions (only for the milled module pieces) with $\Delta \mathrm{pH} \approx 2$ [6]. The data for the eluted $\mathrm{Cd}$ and $\mathrm{Te}$ are presented as concentration in relation to their total mass (i.e., the $100 \%$ value) contained in the prepared CdTe powder/module pieces before the leaching experiments. The leaching lasts up to a time $t=83$ days, partly also to $t=56$ days. Due to our measurements with ICP-MS, we only obtain the amounts of elements which are dissolved in the solutions; precipitates in the solution are not measured by the ICP-MS.

\subsection{Leaching of Untreated CdTe Powder with Different Grain Sizes in pH4}

Figure 3a,b show that $\mathrm{Cd}$ and Te eluted out of CdTe samples follow a dependence on time $t$ with a power law $t^{n}$, with $n=0.43$, as discussed below. In addition, we observe a strong dependence of leaching on the particle size of the CdTe-powder: the smaller the particle diameter, the higher the elution rate. The highest elution rates are obtained for the milled module pieces. The maximum of the y-axis in Figures $3-5$ is $C=100 \%$.

Figure 3a presents detailed data about the release of $\mathrm{Cd}$, termed as $\mathrm{Cd}_{\mathrm{pH}}$, when $\mathrm{Cd}$ is leached out from CdTe powder in and with the solution of $\mathrm{pH}$. The weakest elution is found for the powder $\mathrm{CdTe}_{3000}$ with grain diameters $d_{3000} \leq 3000 \mu \mathrm{m}$ : After $t=56 \mathrm{~d}$, less than $1 \%$ of the $\mathrm{Cd}$ contained in the original powder is found to be dissolved in the leaching solution, i.e., $C d_{3000}(t=56 \mathrm{~d})<1 \%$. For the powder $C d \mathrm{Te}_{840}$, the elution of $C d_{840}$ is one order of magnitude higher, while eluted $C d_{250}$ from $C d e_{250}$ reaches $C d_{250}(t=83 \mathrm{~d})>$ $10 \%$. In addition to the data for the three different $\mathrm{CdTe}$ powders with different maximum grain sizes, Figure $3 a$ also contains leaching results, which we obtain from the milled CdTe module pieces with a thickness $d_{C d T e} \approx 3 \mu \mathrm{m}$ [6]. These data are termed $C d_{3, m}$ in Figure 3a. The data for the milled module pieces closely match the data of the CdTe powders: the instability of the compound CdTe increases with smaller grain sizes. For the leached out concentrations, it clearly holds that $C d_{3000}<C d_{840}<C d_{250}<C d_{3, m}$.

Figure $3 \mathrm{~b}$ presents the data for the elution of $\mathrm{Te}_{\mathrm{pH} 4}$ out of CdTe powder; in addition, we also show data for the elution of Te from the milled module pieces [6]. Again, as for the Cd elution, we find not only the same power law dependence $t^{0} .{ }^{43}$ for the elution, but also $T e_{3000}<T e_{840}<T e_{250}<T e_{3, m}$ for the elution of the Te. 

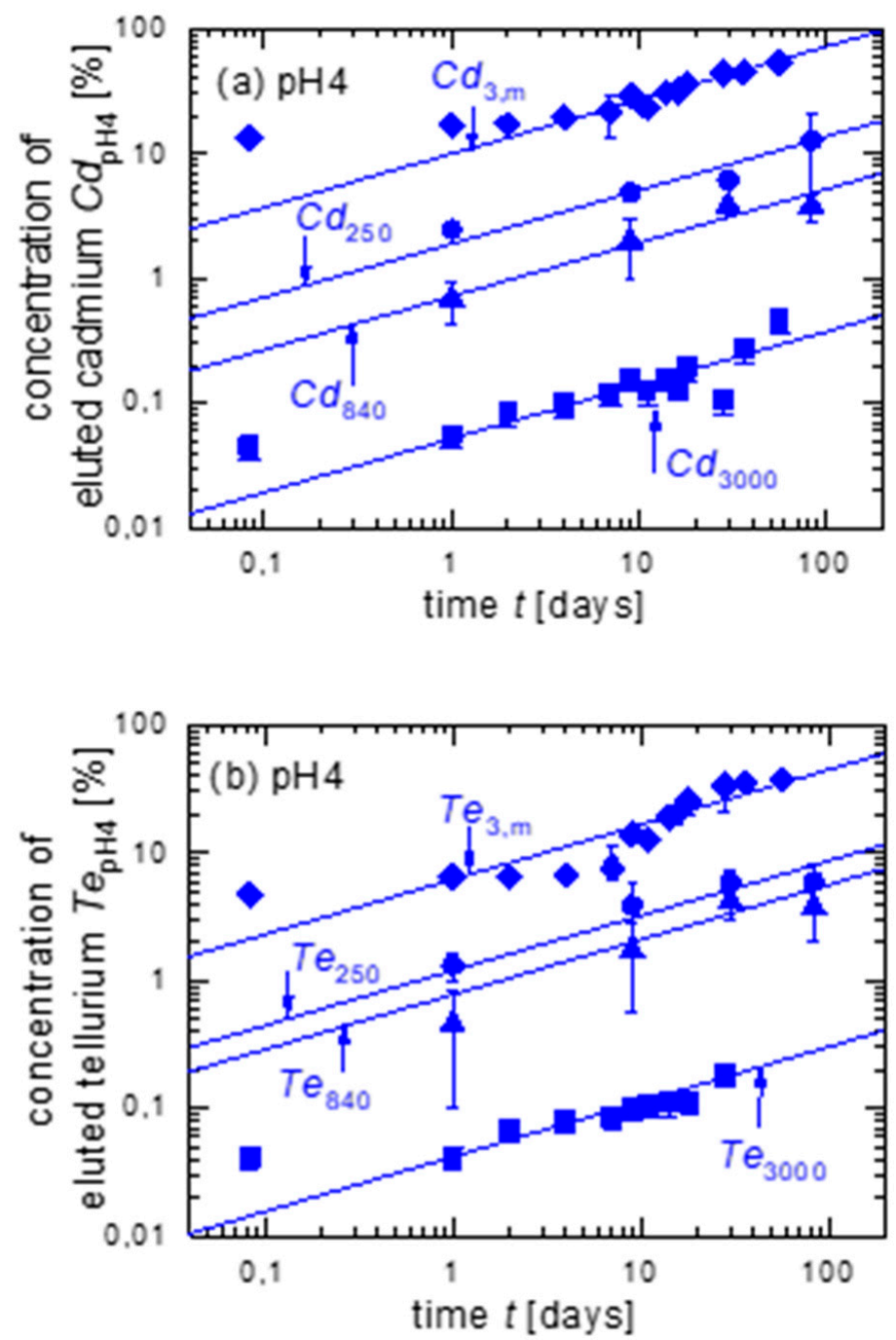

Figure 3. Elution of $\mathrm{Cd}_{p H 4}$ and $\mathrm{Te}_{p H 4}$ in solutions with $\mathrm{pH} 4$ out of three different CdTe powders in comparison to the elution from milled module pieces $C d_{3, m}$ and $\mathrm{Te}_{3, \mathrm{~m}}$ [6] (uppermost curves). Lines in both figures represent simulations after Equation (2), with $C d_{p H 4} \sim t^{n}$ with the diffusional exponent $n=0.43$. (a) $C d_{3000}$ released from powder with $d_{3000} \leq 3000 \mu \mathrm{m}$ shows the weakest elution; the values $C d_{250}$ for powder with $d_{250} \leq 250 \mu \mathrm{m}$ are about a factor of 40 higher. Even higher are the $C d_{3, m}$-values of the milled module pieces: They almost exceed more than $50 \%$ after 56 days. It holds $C d_{3000}<C d_{840}$ $<C d_{250}<C d_{3, m}$. (b) Leaching of Te resembles that of Cd: It holds $T e_{3000}<T e_{840}<\mathrm{Te}_{250}<T e_{3, m}$.

\subsection{Leaching of Untreated CdTe Powder with Different Grain Sizes in $p H 7$}

Figure $4 a, b$ present our data for the elution of CdTe powder in aqueous solutions with $\mathrm{pH7}$. Clearly, the total values for the elution of $\mathrm{Cd}$ as well as of Te are lower than those in pH4 (compare Fissure 3a,b). Nevertheless, we find the same time dependence for both $\mathrm{Cd}$ and Te; their eluted amount increases with $t^{0} .{ }^{43}$. The elution out of $C d_{840}$ and $C d_{3000}$ show small narrow differences. We observe $C d_{3000} \approx C d_{840}<C d_{250}$ as well as $T e_{3000} \approx T e_{840}$ $<\mathrm{Te}_{250}$. Unfortunately, no elution values of milled CdTe modules exist for $\mathrm{pH} 7$. 

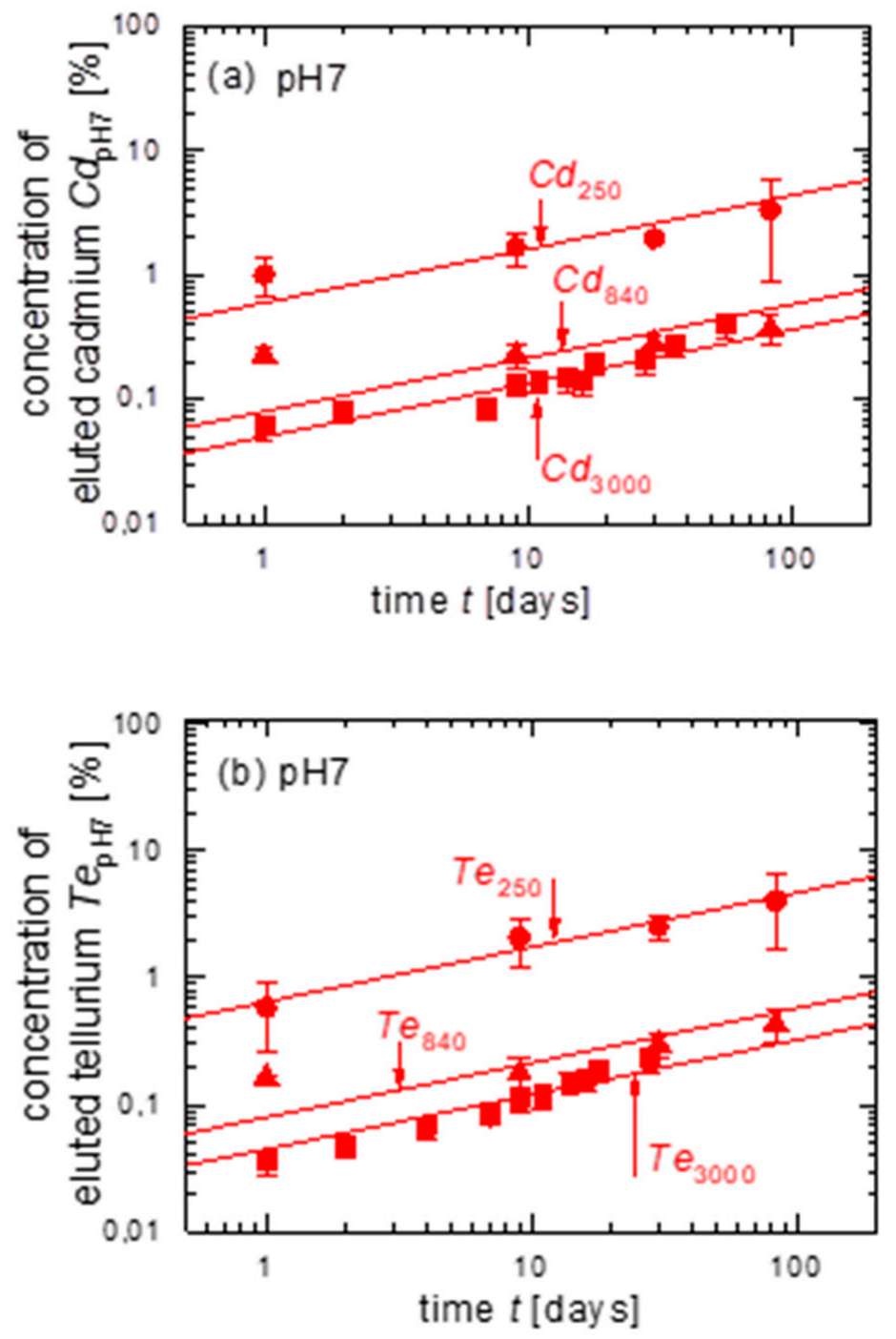

Figure 4. Elution of $\mathrm{Cd}_{p H 7}$ and $\mathrm{Te}_{\mathrm{pH}}$ in solutions with $\mathrm{pH} 7$ out of $\mathrm{CdTe}$ powder. Compared to Figure 2, the absolute values for eluted $\mathrm{Cd}$ and Te are lower. However, we observe the same time dependence $C d_{p H 7} \sim t^{0.43}$ and $T e_{P h 7} \sim t^{0.43}$. (a) The elution of $\mathrm{Cd}$ for the CdTe-powder with the smallest grain diameter is the highest, it holds $C d_{250}>C d_{840} \approx C d_{3000}$. The elution out of $\mathrm{Cd}_{840}$ and $\mathrm{Cd}_{3000}$ show only small differences. (b) Also for Te it holds $\mathrm{Te}_{250}>\mathrm{Te} e_{840} \approx T e_{3000}$. Elution values from milled CdTe-modules are not available for $\mathrm{pH}$.

\subsection{Leaching of Untreated CdTe Powder with Different Grain Sizes in pH10}

Figure $5 \mathrm{a}, \mathrm{b}$ present the stability of the CdTe powders and the milled module pieces [6] in the alkaline solution with pH10. Again, we observe the same time dependence $t^{0}{ }^{43}$ as in Figure $3 \mathrm{a}, \mathrm{b}$ and Figure 4a,b. Also, again, the elution for the milled module pieces is the highest. However, for the CdTe powders, in contrast to the elution in $\mathrm{pH} 4$ and $\mathrm{pH} 7$, now with $\mathrm{pH} 10$, not the powder with the smallest grains is eluted fastest, but the powder with the largest grains in aqueous solutions. In Figure 5a it holds that: $C d_{250} \approx C d_{840}<C d_{3000}<C d_{3, \mathrm{~m}}$. Similarly, for the eluted $T e_{\mathrm{pH} 10}$, illustrated in Figure $4 \mathrm{~b}$, it holds $T e_{3000}<T e_{840}<T e_{250}<T e_{3, \mathrm{~m}}$. In the alkaline range, a higher amount of eluted $T e_{\mathrm{pH} 10}$ than $\mathrm{Cd}_{\mathrm{pH} 10}$ is measured. The elution of $\mathrm{Te}_{3, \mathrm{~m}}$ with $\mathrm{Te}_{3, \mathrm{~m}}(t=56 \mathrm{~d}) \approx 26 \%$ from the milled modules is two orders of magnitude higher when compared to $T e_{250}$ with $T e_{250}(t=83 \mathrm{~d}) \approx 0.3 \%$. 

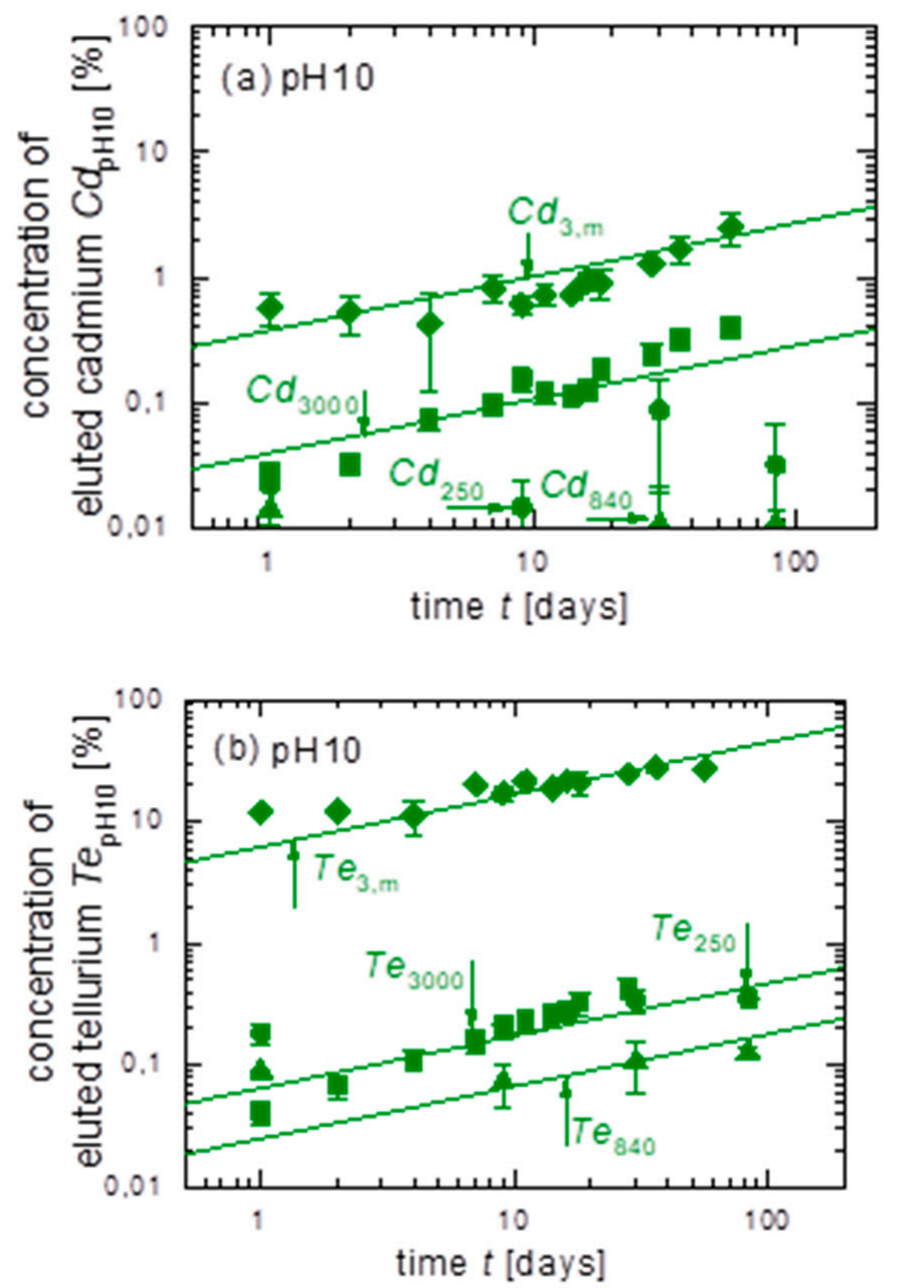

Figure 5. Elution of $C d_{p H 10}$ and $T e_{p H 10}$ in solutions with pH10 out of $\mathrm{CdTe}$ powder and for milled module pieces. (a) The size dependent leaching of $\mathrm{Cd}_{\mathrm{pH} 10}$ changes when compared to the acidic elution in Figure 1. Here it holds $C d_{3, m}>C d_{3000}>C d_{840} \approx C d_{250}$. The $C d_{3, m}$-value for the milled modules pieces is highest. (b) Leaching of $T e_{p H 10}$ is also size dependent. However, for the powders, there is not much difference for the different particle sizes. The lines, again, represent a fit of Equation (5) with the time dependence $t^{0} .^{43}$.

\subsection{Maximum Values after $t=83 d$}

Figure 6 summarizes the data from Figures $3-5$ after 83 days for the maximum concentration of $\mathrm{Cd}$ and $\mathrm{Te}$ that is found in the solutions with different $\mathrm{pH}$. From the $\mathrm{Cd}$ contained in the milled module pieces $(3 \mathrm{~m})$, close to $54 \%$ are leached out in the solution with $\mathrm{pH} 4$. In the same time under the same conditions, $30 \%$ of Te are found in the same solution. For acidic conditions ( $\mathrm{pH} 4$ ) the quantity ratio $\mathrm{Cd}$ :Te in the solution is $\mathrm{Cd}: \mathrm{Te} \approx 2: 1$, for neutral conditions (pH7) it holds Cd:Te $\approx 1: 1$, whereas for alkaline conditions (pH10) it holds $\mathrm{Cd}: \mathrm{Te} \approx 1: 2$.

\subsection{Comparison with Equation (2)}

Table 1 compares the relative leaching ratios of the data in Figures $3-5$ to the values from Equation (2). Here, we take the values for the $\mathrm{CdTe}_{250}$ films as a reference. The data for pH4 agree very well with the expected behavior: The dissolution/elution is proportional to the surface/volume ratio, i.e., to the inverse of the mean particle diameter $d_{\text {mean }}$. For the other $\mathrm{pH}$ values, the prediction goes in the right direction. However, there are noticeable deviations. Note, Equation (2) does not consider that the mean particle size changes during the dissolution. After leaching in aqueous solution with $\mathrm{pH} 4$ for $t=274 \mathrm{~d}$, 


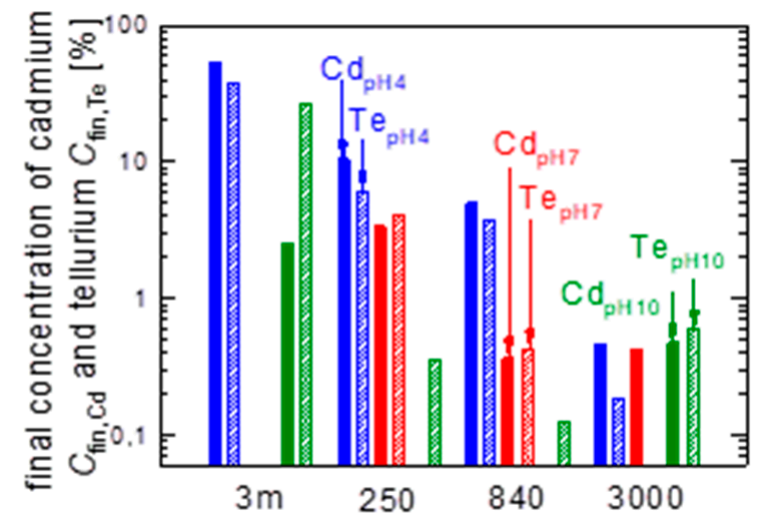

Figure 6. Maximum values of the data from Figures $3-5$ after $t=83$ days, respectively $t=56$ days. For acidic conditions ( $\mathrm{pH} 4$ ) more $\mathrm{Cd}$ than $\mathrm{Te}$ is found in the solution, for neutral conditions ( $\mathrm{pH} 7$ ) the relative amount of $\mathrm{Cd}$ and $\mathrm{Te}$ in solution is about the same, whereas for alkaline conditions (pH10) the tendency is less $\mathrm{Cd}$ than Te in the solution. The smaller the particles, the more $\mathrm{Cd}$ and Te is found in the solutions.

Table 1. Relative ratios of the dilution rates for the different CdTe powders and the milled module pieces compared to the relative surface to volume ratio from Equation (2). For $\mathrm{pH} 4$ the elution of $\mathrm{Cd}$ as well as for Te is in good agreement with Equation (2). For $\mathrm{pH} 7$ there is a noticeable and for $\mathrm{pH} 10$ a strong deviation from Equation (2), in particular if one compares the leached module pieces with the powders for $\mathrm{pH} 10$. For the powders, the elution is much more suppressed, probably via a chemical passivation of the surface of the powder particles.

\begin{tabular}{|c|c|c|c|c|c|c|c|c|c|}
\hline & Figure & $\mathrm{Cd}_{3, \mathrm{~m}} / \mathrm{Cd}_{250}$ & $\mathrm{Cd}_{250} / \mathrm{Cd}_{250}$ & $\mathrm{Cd}_{840} / \mathrm{Cd}_{250}$ & $\mathrm{Cd}_{3000} / \mathrm{Cd}_{250}$ & $\mathrm{Te}_{3, \mathrm{~m}} / \mathrm{Te}_{250}$ & $\mathrm{Te}_{250} / \mathrm{Te}_{250}$ & $\mathrm{Te}_{840} / \mathrm{Te}_{250}$ & $\mathrm{Te}_{3000} / \mathrm{Te}_{250}$ \\
\hline Equation (2) & - & 5 & 1 & 0.5 & $<<0.5$ & 5 & 1 & 0.5 & $<<0.5$ \\
\hline \multirow[t]{2}{*}{$\mathrm{pH} 4$} & $3 a$ & 5.4 & 1 & 0.4 & 0.03 & - & - & - & - \\
\hline & $3 b$ & - & - & - & - & 5 & 1 & 0.5 & 0.03 \\
\hline \multirow[t]{2}{*}{ pH7 } & $4 a$ & - & 1 & 0.15 & 0.1 & - & - & - & - \\
\hline & $4 b$ & - & - & - & - & - & 1 & 0.15 & 0.1 \\
\hline \multirow[t]{2}{*}{ pH10 } & $5 a$ & $\approx 500$ & 1 & $\approx 1$ & 4 & - & - & - & - \\
\hline & $5 b$ & - & - & - & - & $\approx 100$ & 1 & 0.4 & $\approx 1$ \\
\hline
\end{tabular}

$\mathrm{CdTe}_{250}$ and $\mathrm{CdTe}_{840}$ powder show that the smaller particles disappear, leaving particles with larger sizes. Nonetheless, Equation (2) with the assumed mean particle size seems to be valid in Figures 3-5. This assumption is allowed as long as the particles are not completely dissolved, and smaller than the mean particle size. Also, we do not consider any chemistry or hindered transport in the solutions. Also, this simple reflection does not consider any change of the particle distribution upon dissolution. It is just assumed that smaller particles dissolve faster than larger particles. One would also expect that not only the original mean particle sizes, but the exact chemistry of the particles' surface plays a role in the dissolution behavior. For this purpose, we compare CdTe powders with different surface treatment.

\section{Leaching of 'Solar-Cell-Like' Processed CdTe Powder}

Table 1 gives an indication that not only the particle size but also the detailed surface chemistry plays a role in the dilution behavior. Therefore, Figure $7 \mathrm{a}, \mathrm{b}$ compare the influence of solar-cell-like processes on the leaching behavior of the $\mathrm{CdTe}_{250}$ powder in different aqueous solutions. We distinguish:

- $\quad$ Powder $\mathrm{CdTe}_{250}$, untreated, initial powder (blue bars);

- Powder $\mathrm{CdTe}_{250}$, activated by $\mathrm{CdCl}_{2}$ (green bars);

- Powder $\mathrm{CdTe}_{250}$, etched in NP-etch (red bars);

- Powder CdTe 250, activated and etched (grey bars);

- Milled module pieces from Ref. [6] (black bars). 

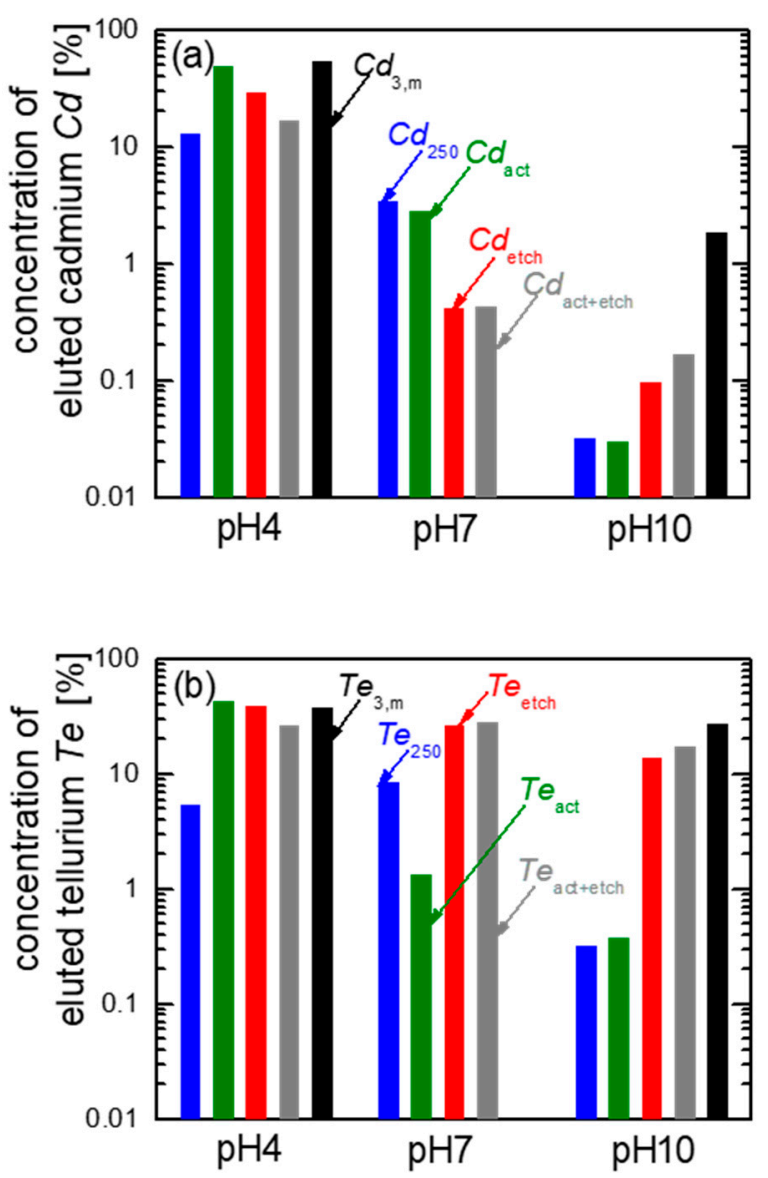

Figure 7. Eluted $\mathrm{Cd}$ and $\mathrm{Te}$ out of $\mathrm{CdTe}_{250}$-powder after $t=83 \mathrm{~d}$ in aqueous solutions with $\mathrm{pH} 4, \mathrm{pH} 7$ and $\mathrm{pH} 10$. The powder is processed like CdTe in solar cells. Data for $C d_{3, m}$ and $\mathrm{Te}_{3, m}$ out of milled CdTe-modules (black data) are only available until $t=56 \mathrm{~d}$ in $\mathrm{pH} 4$ and $\mathrm{pH} 10$ [6]. (a) Activation (green data) increases the elution of $\mathrm{Cd}$ in $\mathrm{pH} 4$. While it holds $C d_{\text {act }}>C d_{250}$ etching to $C d_{\text {etch }}$ (red data) and the combination of activation and etching $C d_{\text {act }+ \text { etch }}$ (grey data) decreases eluted $\mathrm{Cd}$. Nonetheless, however, the data from the milled modules, $\mathrm{Cd}_{3, m}$, (black data) are highest. Leaching in $\mathrm{pH} 7$ and pH10 shows different absolute values. (b) In the case of Te, activation, etching and the combination of both increase the elution of $\mathrm{Te}_{250}$ in $\mathrm{pH} 4$ while in $\mathrm{pH} 7$ and $\mathrm{pH} 10$ only $\mathrm{Te}_{\text {etch }}$ and $\mathrm{Te}_{\text {act }+ \text { etch }}$ increase to $\mathrm{Te}_{3, \mathrm{~m}}$. Activation only decreases the elution of $\mathrm{Te}$ in $\mathrm{pH} 7$ when compared to the unprocessed powder (blue data), while for $\mathrm{pH} 10$, the Te elution is only slightly increased.

The data in Figure 7a, b is taken after eluting with $\mathrm{pH} 4, \mathrm{pH} 7$, and $\mathrm{pH} 10$ after a time $t=83 \mathrm{~d}$ after processing of the CdTe-powders. The data $C d_{3, \mathrm{~m}}$ and $T e_{3, \mathrm{~m}}$ from milled module pieces stem for eluting for $t=56 \mathrm{~d}$.

- $\quad$ pH4: The eluted $\mathrm{Cd}$ of the initial powder is $C d_{250} \approx 10 \%$ (data in blue). Activation (green data) strongly increases the elution to $C d_{\text {act }} \approx 50 \%$, whereas the etching (red data) and the combination of activation plus etching (grey data) decelerates the elution to $C d_{\text {etch }} \approx 30 \%$ and $C d_{\text {act+etch }} \approx 16 \%$.

- $\quad$ pH7: All solar cell like processing steps decrease the elution in $\mathrm{pH} 7$, when compared to the unprocessed powder: the data in blue are still the highest for $\mathrm{pH} 7$.

- $\quad$ pH10: Solar cell-like processing leads to higher elution in $\mathrm{pH} 10$ with the highest value observed for the milled module pieces (see black data $C d_{3, \mathrm{~m}}$ ).

Figure $7 \mathrm{~b}$ shows the amount of eluted Te: in $\mathrm{pH} 4$ the $\mathrm{Te}_{250} \approx 5 \%$ displays the lowest elution, while $T e_{\text {act, }} T e_{\text {etch }}$ and $T e_{\text {act+etch }}$ increase and become close to $T e_{3, \mathrm{~m}} \approx 38 \%$. In solutions with $\mathrm{pH} 7$ and $\mathrm{pH} 10$, the solar cell like processing increases the elution of $\mathrm{Te}$, except the activation step, which decreases eluted Te to $T e_{\text {act }} \approx 1.3 \%$ and $T e_{\text {act }} \approx 0.4 \%$, respectively.

Due to a possible deposition of excess $\mathrm{CdCl}_{2}$ on the $\mathrm{Cd}_{250}$-powder, as shown in Figure 10 by energy-dispersive $\mathrm{X}$-ray (EDX) spectroscopy analysis, the Cd-elution might 
be increased. The mass of $\mathrm{Cd}$-if the whole $\mathrm{Cd}$ out of $\mathrm{CdCl}_{2}$ deposits on $\mathrm{CdTe}$-adds up to an increase in mass of around $7.5 \%$. The increase in the elution between $\mathrm{Cd}_{\mathrm{act}}-\mathrm{CdT}_{250} \approx$ $50-12 \% \approx 38 \%$ is still much higher.

\section{Surface Analysis of CdTe Powder}

Surface Analysis of Leached and Processed CdTe Powder

The solar-cell-like processing and the leaching change the surface conditions and the particle size of the CdTe powders. Here, we present measurements taken from the CdTe-powders $\mathrm{CdTe}_{250}$ and $\mathrm{CdTe}_{840}$. In addition to SEM, we also show EDX data, which identify elements at the surface of the powder grains. For the analysis by SEM the leached powders are filtered by paper filters with a retention of particles with the sizes 7 to $12 \mu \mathrm{m}$. The smallest particles we found in SEM have sizes of around 5 to $7 \mu \mathrm{m}$.

Figure 8a,b show CdTe powder after leaching for $t=274 \mathrm{~d}$ in the aqueous solution with pH4. The same powders before leaching are shown in Figure 1a,b. From the comparison of Figure 1a (before leaching) with Figure 8a (after leaching) for the $\mathrm{CdTe}_{250}$ powder and Figure $1 \mathrm{~b}$ (before leaching) with Figure $8 \mathrm{~b}$ (after leaching) for the CdTe 840 powder, it becomes obvious that in both powders, the smaller particles are dissolved faster than the large particles. This observation is in line with the data of Figure 4a: in the same time, the powder with the smaller grains is eluted faster than the powder with the large grains. Thus, it is understandable, that mainly the largest particles within the powders are left after leaching. Therefore, in the case of both powders, the size distribution of the particles became more homogeneous, when compared to Figure 1a,b. After leaching, the particles in Figure 8 a from the $\mathrm{CdTe}_{250}$ powder have a relatively similar diameter $d_{250,274 \mathrm{~d}} \approx 100 \mu \mathrm{m}$. In contrast, Figure $8 \mathrm{~b}$ from leached CdTe 840 still shows different particle diameters with $d_{840,274 \mathrm{~d}}>100 \mu \mathrm{m}$ and all particles with small diameters (compare to Figure 1b) disappeared completely.
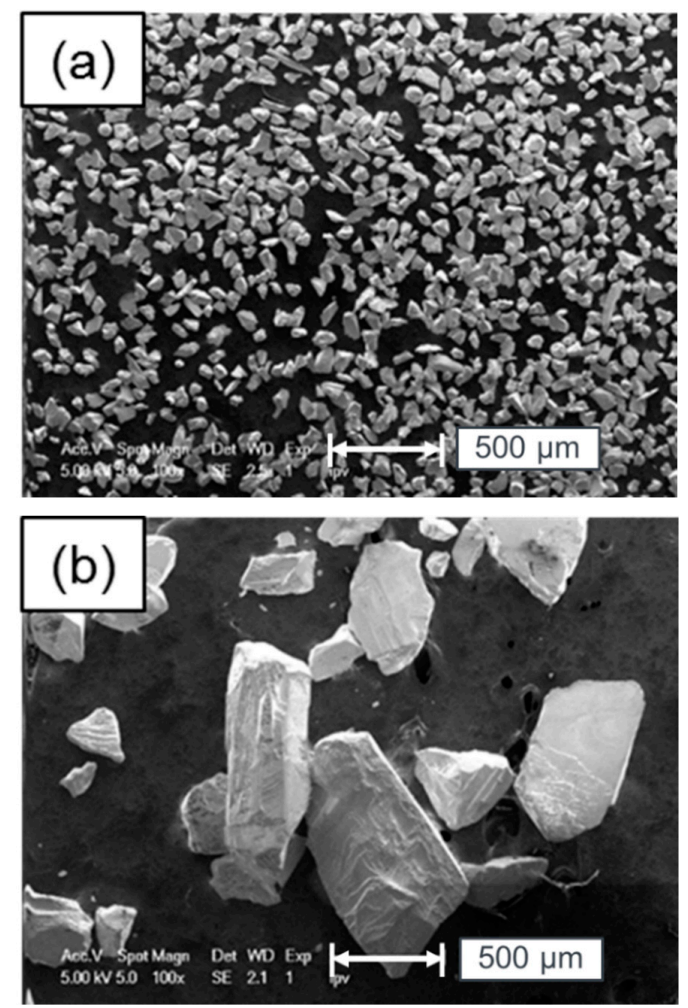

Figure 8. Same CdTe powders as in Figure 1a, b but after leaching in aqueous solution with $\mathrm{pH} 4$ for $t=274 \mathrm{~d}$. (a) In the $\mathrm{CdTe}_{250}$ powder, the smaller particles disappear (compared with Figure 1a), leaving back particles with diameters $d_{250,274 d} \approx 100 \mu \mathrm{m}$. (b) In the $\mathrm{CdTe}_{840}$-powder, the small particles are dissolved fast, leaving back mainly particles with $d_{840,274 d}>100 \mu \mathrm{m}$. 
Leaching and processing of CdTe-powder modifies not only the particles' size and their distribution, but also their surface. The matrix-like Figure 9a-d2 show SEM-pictures of the $\mathrm{CdTe}_{250}$ powders in 12 different stages:

- Figure 9a-d represent the changes due to the "solar-cell-like" processing, all images are taken before leaching.

- Figure 9a1-d1 show the powders from Figure 9a-d after leaching them for $t_{\mathrm{pH} 4}=20 \mathrm{~d}$ in solutions with $\mathrm{pH} 4$.

- Figure $9 \mathrm{a} 2-\mathrm{d} 2$ show the same powders after leaching them for $t_{\mathrm{pH} 4}=274 \mathrm{~d}$ in solutions with $\mathrm{pH} 4$.
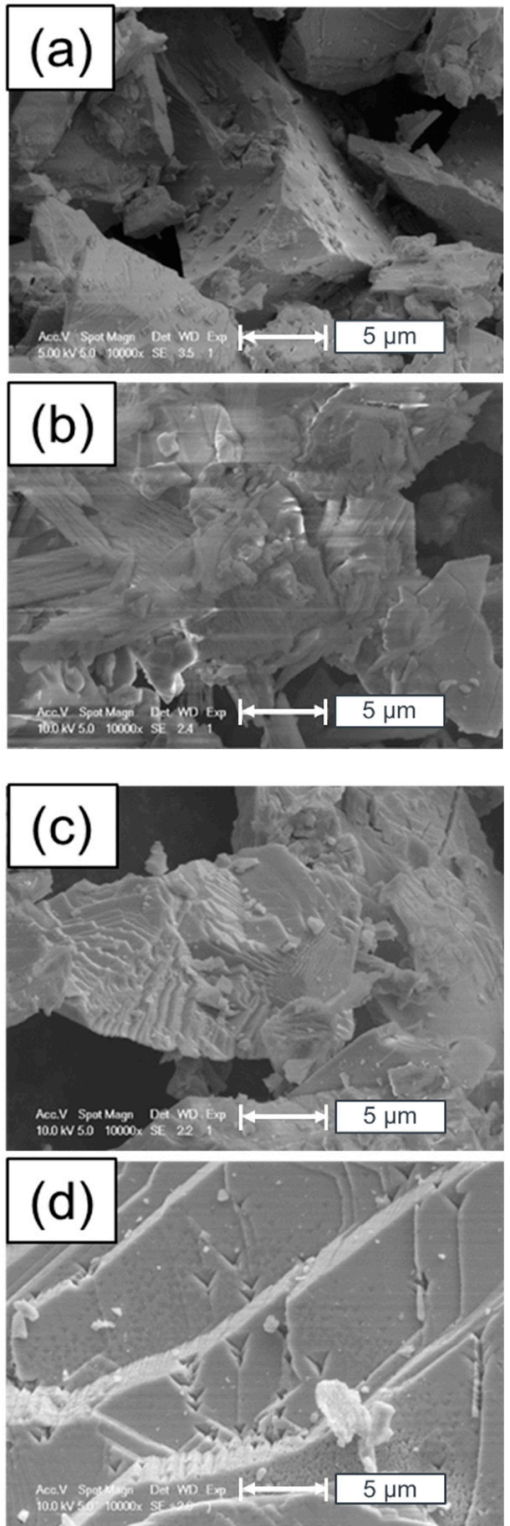
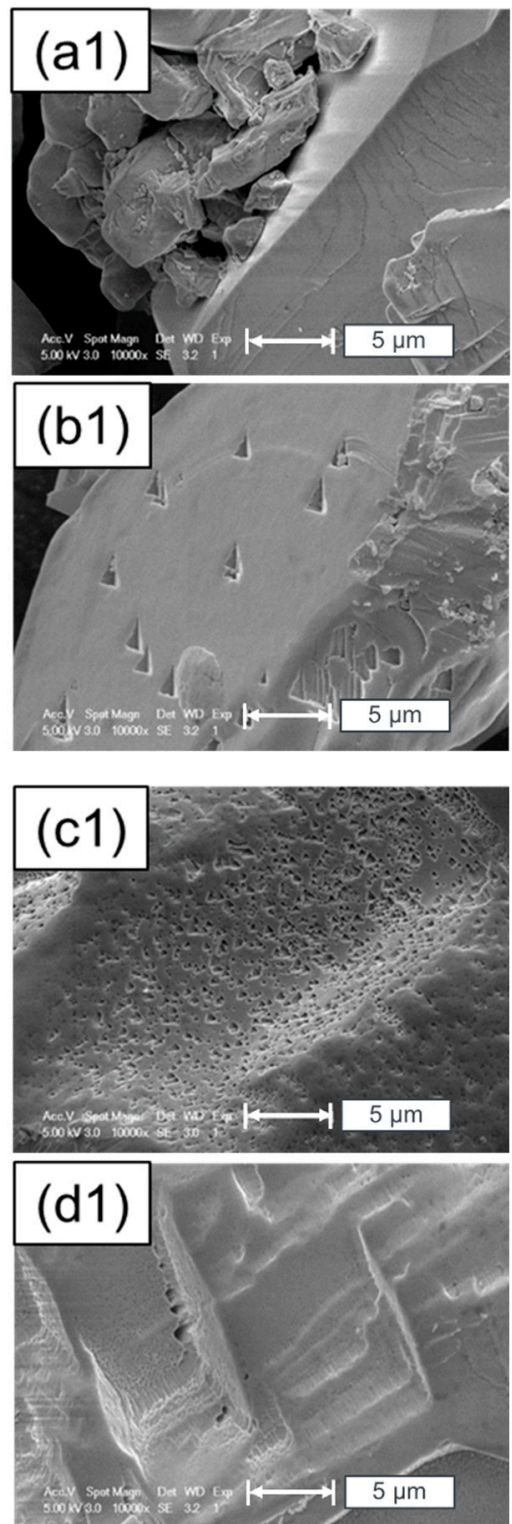
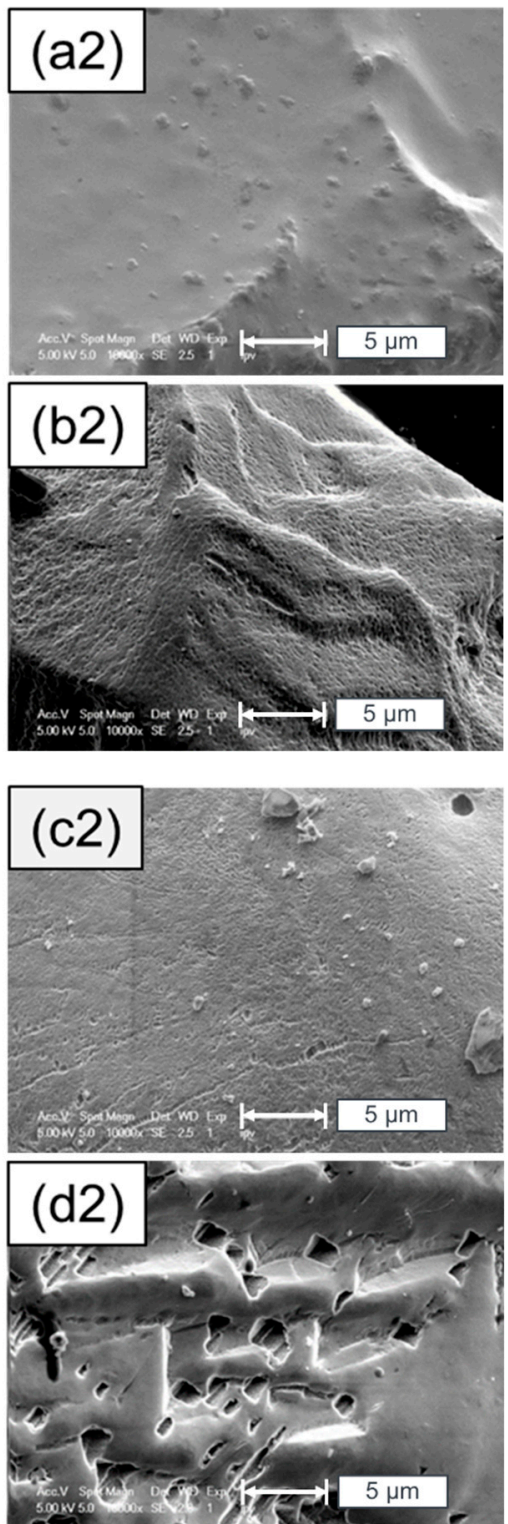

Figure 9. Surface of $\mathrm{CdTe}_{250}$ powder shown by secondary electron images. (a) Initial, untreated powder; (b) "Solar cell-like activation" deposits $\mathrm{CdCl}_{2}$; (c) "solar cell-like etching" forms steps on Table 1. Initially untreated powder after $20 \mathrm{~d}$ of leaching in pH4-solution. (b1) "Activated" powder after 20 days of leaching; (c1) "Etched" powder after $20 \mathrm{~d}$ of leaching; (d1) "Activated and etched" powder after $20 \mathrm{~d}$ of leaching; (a2) Originally untreated powder after 274 d of leaching; (b2) "Activated" powder after $274 \mathrm{~d}$ of leaching. (c2) "Etched" powder after $274 \mathrm{~d}$ of leaching. (d2) "Activated and etched" powder after $274 \mathrm{~d}$. 
Figure 9a presents the rough surface of initial, untreated $\mathrm{CdTe}_{250}$ powder. The "activation" step in the "solar-cell-like" processing deposits $\mathrm{CdCl}_{2}$ on the surface, as indicated in Figure 9b. Figure 9c displays the surface of the CdTe powder after the "etching step" of the "solar-cell-like" processing and Figure 9d shows the surface after "activation plus etching" of the "solar-cell-like" processing.

Each one of the powders from Figure $9 \mathrm{a}-\mathrm{d}$ is now leached out in $\mathrm{pH} 4$ solution: Figure 9a1-d1 show the powders after $t_{p H 4}=20 \mathrm{~d}$, Figure 9a2-d2 after $t_{p H 4}=274 \mathrm{~d}$ of leaching in $\mathrm{pH} 4$ solution.

If one follows the series from Figure $9 \mathrm{a}-\mathrm{a} 2$ one observes that the surface of the initial untreated film from Figure 9a becomes smoother with ongoing leaching. In contrast, the deposition of the $\mathrm{CdCl}_{2}$ via the "activation" (see Figure $9 \mathrm{~b}$ ) leads to an increasing number of etch pits during the leaching (see Figure 9b1,b2) of the active powders. The "etching" forms steps on the grains of the powder, as visible in Figure 9 c. Leaching for $t_{p H 4}=20 \mathrm{~d}$ forms etch pits as shown in Figure 9c1, but after $t_{\mathrm{pH} 4}=274 \mathrm{~d}$ of leaching smoother surfaces are observed (see Figure 9c2). The "activation plus etching" already creates etch steps and pits before leaching in $\mathrm{pH} 4$ solution, as shown in Figure 9d. Short term leaching for $t_{p H 4}=20 \mathrm{~d}$ smoothens the surface, visible in Figure 9d1, while long-term leaching for $t_{\mathrm{pH} 4}=274 \mathrm{~d}$ forms deep etch pits in $\mu \mathrm{m}$-size, as illustrated in Figure $9 \mathrm{~d} 2$.

The "solar cell-like" processing steps change the physical and chemical composition of the CdTe-grains with the consequence of different leaching behavior, when compared to the untreated powders. The change of the chemical properties is confirmed by the different X-ray spectra in Figure 10. The EDX spectra are taken in a scanning electron microscope. To see differences in more detail, the spectra are shifted in the zero line of the counts. Due to "activation" by $\mathrm{CdCl}_{2}$, the composition of the surface of $\mathrm{CdTe}_{\text {act }}$ changes to a higher amount of $\mathrm{Cd}$ and $\mathrm{Cl}$ and a lower amount of Te. The "etching" forms a more Te-rich surface on CdTe etch. However, the combination of "activation plus etching" still leaves more Te on the surface of $\mathrm{CdTe}_{\text {act+etch }}$ which boosts the elution of Te.

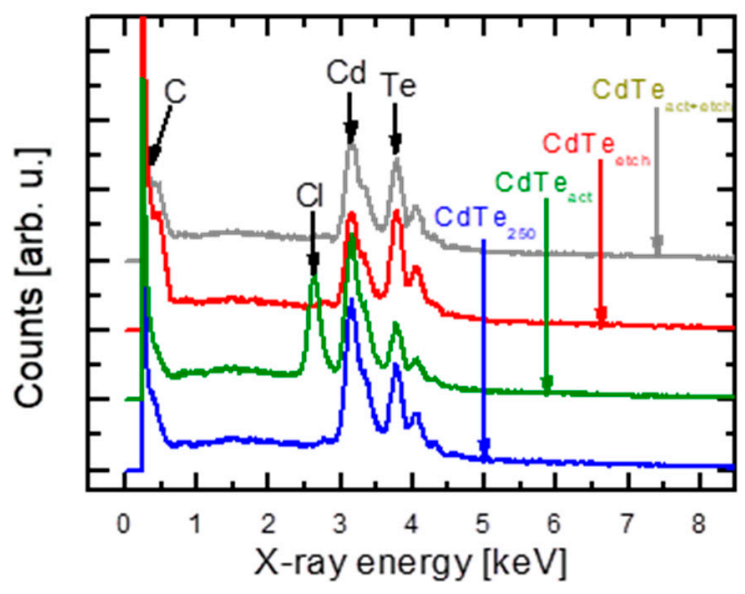

Figure 10. Energy-dispersive X-ray (EDX) spectroscopy data of $\mathrm{CdTe}_{250}$ powders with differently treated surfaces. The surface treatments change the ratio of $\mathrm{Cd}$ to $\mathrm{Te}$ at the surface, represented by the relative heights of the peaks. "Activation" in $\mathrm{CdCl}_{2}$ (green curve) leads to a deposition of $\mathrm{Cl}$ and lowers the Te concentration in relation to Cd. In contrast, "etching" (red curve) increases the Te concentration and lowers the Cd concentration. "activation plus etching" (grey curve) also leaves a (relatively) more Te-rich surface when compared to the original surface (blue curve). Clearly, for Te-rich surfaces, the elution of Te is increased (compare Figure $6 \mathrm{~b}$ ).

\section{Discussion}

\subsection{Thermodynamics and Surface Chemistry}

The experimental data in Figures 3-5 do not show any saturation for leaching out $\mathrm{Cd}$ and/or Te from the CdTe powders as well as from the milled module pieces. Thus, without any question: CdTe powders and module pieces are not stable in aqueous solutions. It is 
only a matter of time, until the CdTe is completely decomposed. Leaching of $\mathrm{Cd}$ and $\mathrm{Te}$ out of CdTe-powder strongly depends on the $\mathrm{pH}$ of the aqueous solutions.

Our results are completely in accordance with earlier data $[27,28]$, which explain the instability of CdTe in aqueous solutions on the basis of thermodynamic considerations: Zeng et al. explained the leaching behavior of CdTe in aqueous solutions with the help of a Pourbaix-diagram for reductive and oxidative conditions [27]. Ramos-Ruiz et al. confirmed these results on CdTe modules [28]. In oxidative conditions, as we measure in our solutions, the probability of the formation of $\mathrm{Cd}^{++}$ions in $\mathrm{pH}<6.9$ is high, whereas for $\mathrm{pH}>6.9$ the released $\mathrm{Cd}$ forms the compound cadmium hydroxide $\mathrm{Cd}(\mathrm{OH})_{2}$. The $\mathrm{Cd}(\mathrm{OH})_{2}$ precipitates in water and is not accessible in our measurements of dissolved elements. Formation of $\mathrm{Cd}^{++}$ions in low $\mathrm{pH}$ and a precipitation of $\mathrm{Cd}(\mathrm{OH})_{2}$ in higher $\mathrm{pH}$ is in agreement with our elution results. Except in acidic solutions, Te elutes in a higher amount than $\mathrm{Cd}$. The Pourbaix diagram indicates a generation of non-soluble tellurium oxide $\mathrm{TeO}_{2}$ at low $\mathrm{pH}$, whereas in alkaline conditions the formation of soluble Te ions predominates.

\subsection{Particle Size and Time-Dependent Elution}

Dependence on particle size: the data in Figure 3 and Table 1 (in particular for $\mathrm{pH} 4$ ) reveal the strong influence of the particle size on elution. Smaller particles dissolve faster than larger particles. Such behavior is well known in the field of pharmacy: Hintz et al. [29] increased the dissolution of drugs by milling them to smaller particle sizes. The study indicated that the solubility is proportional to the inverse diameter of the particles if in the micrometer range, just as assumed in our Equation (2). As a consequence, during elution/dissolution, the particle distribution will become more homogeneous: the larger particles survive longest.

Time dependence: apart from the detailed influence of the surface, as well as of the particle size/distribution, as well as of the $\mathrm{pH}$, we observe a universal behavior: Figure $3 \mathrm{a}, \mathrm{b}$, Figure $4 \mathrm{a}, \mathrm{b}$ and Figure $5 \mathrm{a}, \mathrm{b}$ reveal a particular dependence of the eluted concentration $C$ on time $t$. Before saturation is reached, the concentration $C$ of the eluted elements follows a power law

$$
C \propto t^{n}
$$

In our case, we find $n=0.43 \pm 0.02$.

Our experimental result with $n=0.43$ from leaching CdTe-powders in different $\mathrm{pH}$ is in agreement with an earlier pharmaceutic model of Ritger and Peppas [30]. They modeled the release of drugs from polymeric devices. Similar to our system, where $\mathrm{Cd}$ and Te are released from CdTe particles, they modelled the release of drugs from polymeric devices of different shapes. As in their case, also in our case, the "drugs" $\mathrm{Cd}$ and Te are dissolved at the surface of the particles, then they diffuse into the solvent. Ritger and Peppas [30] assumed a Fickian diffusion within the polymeric matrix. Earlier it was shown by Crank [31], that the mathematically exact solution for a diffusion from spherical particles with radius $r$ is

$$
\frac{C(t)}{C_{\infty}}=1-\frac{6}{\pi^{2}} \sum_{n=1}^{\infty} \frac{1}{n^{2}} \exp \left(\frac{-D n^{2} \pi^{2} t}{r^{2}}\right)
$$

Here, in our notation, $C(t)$ is the eluted concentration of the "drug" (e.g., $C d, T e$ ) in the solution, $C_{\infty}$ stands for the mass $C$ for time $t=\infty$, and $D$ is the diffusion constant of the drug (i.e., Cd, Te) within the surface of the CdTe matrix. Instead of the complete Equation (4), a good approximation to Equation (4) for the first $60 \%$ of drug release is given by [30]

$$
\frac{C(t)}{C_{\infty}}=k t^{n}
$$

Equation (5) is a good approximation not only to Equation (4) for spheres, but also to the respective mathematical solutions for other geometries: for thin films and cylinders instead of spheres [31]. If the dissolution is limited by diffusion in the matrix, then it holds that $n=0.5$ for thin films, $n=0.45$ for cylindrical particles and $n=0.432 \pm 0.007$ 
for spherical particles of uniform size. These $n$-values are a good approximation for the first $60 \%$ release. For the first $10 \%$ to $15 \%$ release from spherical particles, $n=0.5$ is also a good approximation. If one considers not only spheres of the same size, but also size distributions, one obtains $n$-values between $n=0.41$ to $n=0.43$ [30].

The elution behavior in Figures 3-5 is well described by Equation (5) with $n=0.43$. It is also understandable why a size distribution of spheres does not change much the exponent $n$ : the smaller particles accelerate the outdiffusion and the elution, the larger particles lead to retardation of the diffusion process within the CdTe particles.

The elution behavior from the spheres is different but not much far from a time dependence with $n=0.5$. In this case, it holds for particles with a diameter $d$ [30]:

$$
\frac{C_{t}}{C_{\infty}}=4\left(\frac{D t}{\pi r^{2}}\right)^{\frac{1}{2}}=8 \sqrt{\frac{D t}{\pi d^{2}}}
$$

Here, $D$ is the diffusion constant of the diffusing substance within the matrix of the drug. In our interpretation, $D$ is the diffusion constant $D_{C d}$ of $C d$ and $D_{T e}$ of Te within the CdTe particles. The $\mathrm{Cd}$ and the Te diffuse to the surface of the CdTe particles, and the solution acts as a perfect sink for $\mathrm{Cd}$ and Te just as in the pharmaceutic model.

Equation (6) allows us to estimate the diffusion constant $D$ from measured values of the eluted mass $C_{t}=\mathrm{C}(\mathrm{t})$ at time $t$ with respect to the value $C_{\infty}$, the saturation value at $t=\infty$ and the diameter $d$ of the particles, according to

$$
D=\frac{\pi}{64}\left(C_{t} / C_{\infty}\right)^{2} \frac{d^{2}}{t}
$$

We derive the $D$-values from the data in Figure $3 \mathrm{a}$ for $\mathrm{pH} 4$ and the $\mathrm{Cd}$-elution from the milled module pieces (uppermost curve), assuming $d=d_{\text {mean } \text {,mod }}=1 \mu \mathrm{m}$. The extrapolation shows that the extrapolated $C_{\infty}$-value for the $C d_{3, m}$-data is reached after $t=200 \mathrm{~d}$. At this time, it holds $C_{t}=C_{200}=C_{\infty}=100 \%$ and $C_{t} / C_{\infty}=1$. From these values, we obtain $D_{C d} \approx 3 \times 10^{-17} \mathrm{~cm}^{2} / \mathrm{s}$ for the diffusion constant of $\mathrm{Cd}$. In case of the Te-elution, the extrapolated $100 \%$ value would be reached after 400 days. This yields a diffusion constant $D_{\mathrm{Te}} \approx 1.5 \times 10^{-17} \mathrm{~cm}^{2} / \mathrm{s}$ for Te. The shift downwards of the other curves in Figure $3 \mathrm{a}, \mathrm{b}$ with respect to those of the milled module pieces within one figure is simply explained with the larger particle sizes: the powders contain larger particles than the milled module pieces. Therefore, it simply takes longer to reach the saturation value.

For the calculation of $D_{C d}$ and $D_{T e}$ from Equation (7) we have to assume the value $C_{\infty}$ for the $\mathrm{Cd}$ as well as for the Te. For the determination of the diffusion constants from the data for $\mathrm{pH} 4$ in Figure 3a,b we assume that this value is at 100\% of the amount of $\mathrm{Cd}$ and $\mathrm{Te}$, which are contained in the CdTe particles, simply because the experimental data $\mathrm{Cd}_{3, \mathrm{~m}}$ and $\mathrm{Te}_{3, \mathrm{~m}}$ come close to $100 \%$. Thus, if we had just measured long enough, all the $\mathrm{Cd}$ and Te would have been found in the solution. However, this assumption is not generally valid: the values $C_{\infty}$ for $\mathrm{Cd}$ and Te cannot exceed the solubility limits of the solution. Therefore, generally, even if the CdTe particles were dissolved completely, part of the $\mathrm{Cd}$ and Te could fall out in the form of precipitates. In the case of $\mathrm{Cd}$, these are cadmium hydroxides. Such precipitates are not detected by our analysis method. We only measure the dissolved $\mathrm{Cd}$ and Te. However, the data for $\mathrm{pH} 4$ approach the $100 \%$ for $\mathrm{Cd}$ as well as for Te. Therefore, for this $\mathrm{pH}$ the amount of precipitates can be neglected.

The result for the lower diffusion constant $D_{T e}$ for Te compared to $D_{C d}$ for $\mathrm{Cd}$ stems from the shift downwards of the Te curves in Figure $3 \mathrm{~b}$ when compared to the Cd curves in Figure 3a. Note, these diffusion constants hold for room temperature. Therefore, it is not easy to compare them to literature data [32-34], which are taken at temperatures above $500{ }^{\circ} \mathrm{C}$. In 2015 Shcherbak et al. [35] analyzed the literature data for diffusion in $\mathrm{CdTe}$ in the high-temperature regime. For most diffusing species in CdTe there holds an Arrhenius law for the dependence of the diffusion constants $D$ on absolute temperature $T$ according to $D=D_{0} \exp \left(-E_{A} / k T\right)$ with prefactor $D_{0}$ and activation energy $E_{A}$. Depending 
on the experimental technique as well as on the diffusion mechanism (e.g., interstitial, vacancy) and charge, there is substantial scatter even for $\mathrm{Cd}$ and Te and even for the high-temperature regime. In our case for room temperature, we neither know the charge nor the diffusion mechanisms for $\mathrm{Cd}$ and Te but, probably, they diffuse as neutral species. To put our data in perspective, we compare them to the radiotracer self-diffusion data in Figures 2, 3, 5 and 6 of reference [34], which also showed Arrhenius-type behavior in the high temperature regime $(T>1000 \mathrm{~K})$ with exponential tails for lower temperatures, and absolute values of $D \approx 10^{-13} \mathrm{~cm}^{2} / \mathrm{s}$ at $T \approx 800 \mathrm{~K}$. If we extrapolate the data in the Arrhenius plots of reference [34] data towards room temperature $T \approx 300 \mathrm{~K}$, our results with $D \approx 10^{-17} \mathrm{~cm}^{2} / \mathrm{s}$ range in an expected order of magnitude. There seems to be also agreement that the diffusivity of Te in CdTe is smaller than that of Cd. Thus, our data fit into the trend of the literature data towards lower temperatures. These findings support our assumption that the elution of $\mathrm{Cd}$ and Te out of the CdTe is mainly controlled by the diffusion of $\mathrm{Cd}$ and $\mathrm{Te}$ in and across the surface of the particles. The solution acts as a perfect sink because, during the experiment, we shake the containers with the solutions and the powders/particles.

The behavior of the data for $\mathrm{Cd}$ for $\mathrm{pH} 7$ and $\mathrm{pH} 10$ is different, but also understood. Compared to the $\mathrm{Cd}$-data for $\mathrm{pH} 4$, for the same elution time $t$, we find much less $\mathrm{Cd}$ in the solution. We explain this finding with the formation of $\mathrm{Cd}$-containing precipitates: Depending not only on the $\mathrm{pH}$, but also on the kind of solvent, $\mathrm{Cd}$ forms different hydroxides in water-based solutions. For $\mathrm{pH} 4$, the species distribution plots of $\mathrm{Cd}[35,36]$ show only $\mathrm{Cd}^{2+-}$ ions. The higher the $\mathrm{pH}$, depending on the redox potential, the more hydroxides that appear. The species distribution plot of Wilkin [36] shows $100 \%$ of $\mathrm{Cd}^{2+}$ at $\mathrm{pH} 4$. In contrast, at $\mathrm{pH} 10$, much less $\mathrm{Cd}^{2+}$ is available. Therefore, it is understandable that the Cd curves in Figure 5a are shifted downwards: the extrapolated data for the $\mathrm{Cd}_{3 \mathrm{~m}}$-pieces for $\mathrm{pH} 4$ (Figure 3a) and $t=200 \mathrm{~d}$ end up at $C_{\infty} \approx 100 \%$, whereas the data for the $\mathrm{Cd}_{3 \mathrm{~m}}$-pieces for pH10 (Figure $5 \mathrm{a}$ ) and $t=200 \mathrm{~d}$ end up at $C_{\infty} \approx 4 \%$. This means that only about $4 \%$ of the $\mathrm{Cd}$ will go into solution for $\mathrm{pH} 10$, if we ascribe all missing $\mathrm{Cd}$ in the solution to precipitates. Under this assumption the missing $96 \%$ of $\mathrm{Cd}$ in case of $\mathrm{pH} 10$ would precipitate in the form of hydroxides. The data for pH7 in Figure $4 \mathrm{a}$ lie between the data from Figures $3 \mathrm{a}$ and $5 \mathrm{a}$. Therefore, we also expect some precipitation of hydroxides even for $\mathrm{pH7}$. However, it is also possible that for $\mathrm{pH} 7$ a surface layer preventing outdiffusion is formed.

In contrast to the Cd-data, we do not have an indication for the formation of Te precipitates for $\mathrm{pH} 7$ and $\mathrm{pH} 10$. We speculate that the lower values in Figures $4 \mathrm{~b}$ and $5 \mathrm{~b}$ compared to Figure $3 \mathrm{a}$ are related to the surface of the CdTe. For the Te, apart from a substantial scatter of the data in Figures $4 \mathrm{~b}$ and $5 \mathrm{~b}$ for the larger particles, there is almost no change of the data for different $\mathrm{pH}$, in particular for the milled module pieces. The $\mathrm{Te}_{3, \mathrm{~m}}$-data for pH4 (Figure 3a) and pH11 (Figure 5a) agree almost exactly with each other. Therefore, it seems that-independent of $\mathrm{pH}$ - there is no formation of precipitates for Te. Obviously, we are far from the solubility limit for Te. The scatter of the data for larger particle sizes, probably is a consequence of a passivation of the surface by tellurium oxide. In this case, the etching/outdiffusion of Te would also be hindered with the consequence of a lower diffusion constant.

\section{Conclusions}

Our time-dependent leaching experiments have demonstrated severe leaching of $\mathrm{Cd}$ out of CdTe which is not finished until day 83. The measured elution of $\mathrm{Cd}$ and Te indicates a destabilization and corrosion of the compound CdTe. The CdTe particles are not stable in water, even for neutral water with $\mathrm{pH} 7$.

Our leaching experiments on CdTe particles with different sizes are not only qualitatively but also quantitatively understood:

- The faster dissolution for the smaller particles is simply understood by their larger surface to volume ratio. The dissolution rate is proportional to the inverse diameter. 
- The time-dependent aggregation of the dissolved species with $t^{0.43}$ is understood on the basis of a model that, originally, stems from pharmacy. The dissolution is controlled by the diffusion of $\mathrm{Cd}$ and $\mathrm{Te}$ in and across the surface of the spherical particles.

- The total behavior of the data in Figures 3-5 is understood on the basis of the room temperature diffusion coefficients $D_{C d} \approx 3 \times 10^{-17} \mathrm{~cm}^{2} / \mathrm{s}$ for the $\mathrm{Cd}$, and $D_{T e} \approx 1.5 \times 10^{-17} \mathrm{~cm}^{2} / \mathrm{s}$ for Te.

Author Contributions: Conceptualization, R.Z.-G. and M.K.; Funding acquisition, R.Z.-G.; Investigation, R.Z.-G., M.Z., J.N. and C.F;; Methodology, R.Z.-G. and M.K.; Project administration, R.Z.-G.; Resources, J.N.; Validation, J.H.W.; Visualization, J.N.; Writing—review \& editing, R.Z.-G., M.K. and J.H.W. All authors have read and agreed to the published version of the manuscript.

Funding: Parts of this work were funded by the German Federal Ministry of Economics and Technology (BMWi) project No. 0325718.

Institutional Review Board Statement: Not applicable.

Informed Consent Statement: Not applicable.

Data Availability Statement: Not applicable.

Acknowledgments: The authors thank Christine Herrmann (Institute for Modelling Hydraulic and Environmental Systems, University of Stuttgart) for the BET measurements.

Conflicts of Interest: The authors declare no conflict of interest.

\section{References}

1. Patterson, M.; Turner, A.; Sadeghi, M.; Marshall, R. Health, safety and environmental aspects of the use of cadmium compounds in thin film PV modules. Sol. Energy Mater. Sol. Cells 1994, 35, 305-310. [CrossRef]

2. Fthenakis, V.M. Life cycle impact analysis of cadmium in CdTe PV production. Renew. Sustain. Energy Rev. 2004, 8, 303-334. [CrossRef]

3. Kato, K.; Hibino, T.; Komoto, K.; Ihara, S.; Yamamoto, S.; Fujihara, H. A life-cycle analysis on thin-film CdS/CdTe PV modules. Sol. Energy Mater. Sol. Cells 2001, 67, 279-287. [CrossRef]

4. Bohland, V.J.; Anisimov, I.I.; Dapkus, T.J.; Sasala, R.A.; Smigielski, K.A.; Kamm, K.D. Reclaiming Metallic Material from an Article Comprising a Non-Metallic Friable Substrate. U.S. Patent No. US 6129779 A, 10 October 2000.

5. Wang, W.; Fthenakis, V. Kinetics study on separation of cadmium from tellurium in acidic solution media using ion-exchange resins. J. Hazard. Mater. 2005, 125, 80-88. [CrossRef]

6. Zapf-Gottwick, R.; Koch, M.; Fischer, K.; Schwerdt, F.; Hamann, L.; Kranert, M.; Metzger, J.; Werner, J. Leaching Hazardous Substances out of Photovoltaic Modules. Int. J. Adv. Appl. Phys. Res. 2015, 2, 7-14. [CrossRef]

7. Nover, J.; Zapf-Gottwick, R.; Feifel, C.; Koch, M.; Metzger, J.W.; Werner, J.H. Long-term leaching of photovoltaic modules. Jpn. J. Appl. Phys. 2017, 56, 08MD02. [CrossRef]

8. Mitchell, K.W.; Fahrenbruch, A.L.; Bube, R.H. Photovoltaic determination of optical-absorption coefficient in CdTe. J. Appl. Phys. 1977, 48, 829-830. [CrossRef]

9. Birkmire, R.W.; Candless, B.E. CdTe thin film technology: Leading thin film PV into the future. Curr. Opin. Solid State Mater. Sci. 2010, 14, 139-142. [CrossRef]

10. Bonnet, D. Manufacturing of CSS CdTe solar cells. Thin Solid Films 2000, 361, 547-552. [CrossRef]

11. Institut für Arbeitsschutz der DGUV. GESTIS-Stoffdatenbank. Available online: https: / / gestis.dguv.de/data?name=109355 (accessed on 8 January 2021).

12. Terheggen, M.; Heinrich, H.; Kostorz, G.; Baetzner, D.; Romeo, A.; Tiwari, A. Analysis of Bulk and Interface Phenomena in CdTe/CdS Thin-Film Solar Cells. Interface Sci. 2004, 12, 259-266. [CrossRef]

13. Bosio, A.; Menossi, D.; Mazzamuto, S.; Romeo, N. Manufacturing of CdTe thin film photovoltaic modules. Thin Solid Film. 2011, 519, 7522-7525. [CrossRef]

14. Emziane, M.; DuRose, K.; Romeo, N.; Bosio, A.; Halliday, D. Effect of $\mathrm{CdCl} 2$ activation on the impurity distribution in CdTe/CdS solar cell structures. Thin Solid Film. 2005, 480, 377-381. [CrossRef]

15. Rosenberg, R.J.; Zilliacus, R.; Lakomaa, E.L.; Rautiainen, A.; Mäkelä, A. Study of CdTe/CdS-thin films by isotope dilution, neutron activation analysis, inductively coupled plasma mass spectroscopy and secondary ion mass spectroscopy. Fresenius J. Anal. Chem. 1996, 354, 6-10. [CrossRef]

16. MilliporeSigma. Available online: www.sigma-aldrich.com (accessed on 18 December 2020).

17. Kraft, D.; Thissen, A.; Broetz, J.; Flege, S.; Campo, M.; Klein, A.; Jaegermann, W. Characterisation of tellurium layers for back contact formation on close to technology treated CdTe surfaces. J. Appl. Phys. 2003, 94, 3589-3598. [CrossRef] 
18. Zorn, M. Solubility of cadmium telluride. Bachelor's Thesis, Institute for Photovoltaics, University of Stuttgart, Stuttgart, Germany, 2015. Chapter 4.

19. Hajimammadov, R.; Fathi, N.; Bayramov, A.; Khrypunov, G.; Klochko, N.; Li, T. Effect of “CdCl2Treatment" on Properties of CdTe-Based Solar Cells Prepared by Physical Vapor Deposition and Close-Spaced Sublimation Methods. Jpn. J. Appl. Phys. 2011, 50, 05FH01. [CrossRef]

20. McCandless, B.E.; Dobson, K.D. Processing options for CdTe thin film solar cells. Sol. Energy 2004, 77, 839-856. [CrossRef]

21. Mack, S. Herstellung und Charakterisierung von CSS-CdTe-Dünnschicht-Solarzellen. Diploma's Thesis, Friedrich-SchillerUniversität Jena, Jena, Germany, 2006.

22. De Mello, W.Z.; de Almeida, M.D. Rainwater chemistry at the summit and southern flank of the Itatiaia massif, Southeastern Brazil. Environ. Pollut. 2004, 129, 63-68. [CrossRef] [PubMed]

23. Hochschule für Angewandte Wissenschaften (HAW) Hamburg. Available online: http://www.haw-hamburg.de/fileadmin/user_ upload/FakLS/08LABORE/Chemie/Regenwasseranalyse/Regenwasser_Analyse_WS_12_13_Els.pdf (accessed on 1 September 2017).

24. Landesamt für Natur, Umwelt und Verbraucherschutz Nordrhein-Westfalen (lanuv). Fachbericht 24, Beschaffenheit von Deponiesickerwässer. 2012. Available online: http://www.lanuv.nrw.de, (accessed on 1 September 2017).

25. Marion, G.M.; Millero, F.J.; Camões, M.F.; Spitzer, P.; Feistel, R.; Chen, C.T. pH of seawater. Mar. Chem. 2011, 126, 89-96. [CrossRef]

26. Alcademics. Available online: http://www.alcademics.com/2013/04/measuring-ph-of-mineral-waters.html (accessed on 1 September 2017).

27. Zeng, C.; Ramos-Ruiz, A.; Field, J.A.; Sierra-Alvarez, R. Cadmium telluride (CdTe) and cadmium sulfide (CdS) leaching behavior and surface chemistry in response to $\mathrm{pH}$ and $\mathrm{O}_{2}$. J. Environ. Manag. 2015, 154, 78-85. [CrossRef]

28. Ramos-Ruiz, A.; Wilkening, J.V.; Field, J.A.; Sierra-Alvarez, R. Leaching of cadmium and tellurium from cadmium telluride (CdTe) thin-film solar panels under simulated landfill conditions. J. Hazard. Mater. 2017, 336, 57-64. [CrossRef]

29. Hintz, R.J.; Johnson, K.C. The effect of particle size distribution on dissolution rate and oral absorption. Int. J. Pharm. 1989, 51, 9-17. [CrossRef]

30. Ritger, P.L.; Peppas, N.A. A simple equation for description of solute release. I. Fickian and non-Fickian release from non-swellable devices in the form of slabs, spheres, cylinders or discs. J. Control. Release 1987, 5, 23-26. [CrossRef]

31. Crank, J. The Mathematics of Diffusion; Clarendon Press: Oxford, UK, 1875.

32. Zanio, K. Chemical Diffusion in Cadmium Telluride J. Appl. Phys. 1970, 41, 1935-1940. [CrossRef]

33. Kröger, F.A. The defect structure of CdTe. Rev. Phys. Appl. 1977, 12, 205-210. [CrossRef]

34. Borsenberger, P.M.; Stevenson, D.A. Self-diffusion of Cd and Te in CdTe. J. Phys. Chem. Solids 1968, 29, 1277. [CrossRef]

35. Shcherbak, L.; Kopach, O.; Fochuk, P.; Bolotnikov, A.E.; James, R.B. Empirical Correlations between the Arrhenius Parameters of Impurities' Diffusion Coefficients in CdTe Crystals. J. Phase Equilibria Diffus. 2015, 36, 99-109. [CrossRef]

36. Wilkin, R.T. Cadmium. In Monitored Natural Attenuation of Inorganic Contaminants in Ground Water; Ford, R.G., Wilkin, R.T., Puls, R.W., Eds.; U.S. Environmental Protection Agency: Ada, OK, USA, 2007; Volume 2, pp. 1-9. 